American University Washington College of Law

Digital Commons @ American University Washington College of

Law

Articles in Law Reviews \& Other Academic Journals

Scholarship \& Research

2007

Market Definition: An Analytical Overview

Jonathan Baker

Follow this and additional works at: https://digitalcommons.wcl.american.edu/facsch_lawrev

Part of the Antitrust and Trade Regulation Commons, and the Law and Economics Commons 


\title{
MARKET DEFINITION: AN ANALYTICAL OVERVIEW
}

\author{
JONATHAN B. BAKER*
}

Throughout the history of U.S. antitrust litigation, the outcome of more cases has surely turned on market definition than on any other substantive issue. Market definition is often the most critical step in evaluating market power and determining whether business conduct has or likely will have anticompetitive effects. ${ }^{1}$

This survey addresses the reasons for undertaking market definition in antitrust analysis and methods of doing so. ${ }^{2}$ It discusses how the process of market definition should be conducted, with attention to the practical difficulties of doing so. Among other things, it explains why markets should be defined based solely with reference to demand substitution, leaving supply substitution considerations for other steps of competitive effects analysis, and identifies five types of evidence as to buyer substitution. The article also discusses the appropriate scope of markets (including submarkets) and explains why four approaches sometimes employed for market definition (price correlations, shipment flows, critical loss analysis, and cluster markets) should be avoided. In addition, it analyzes how market definition differs depending on whether the alleged harm is prospective or retrospective and depending upon whether the anticompetitive theory involves collusion or exclusion.

\footnotetext{
* Professor of Law, Washington College of Law, American University. I am particularly indebted to Bobby Willig for conducting an informal seminar about market definition with me over many years. I am also grateful to Rich Gilbert, Astrid Jung, Steve Salop, Carl Shapiro, and Vincent Verouden for helpful discussions and comments.

${ }^{1}$ Eastman Kodak Co. v. Image Technical Servs., Inc., 504 U.S. 451, 469 n.15 (1992) ("Because market power is often inferred from market share, market definition generally determines the result of the case."); Robert Pitofsky, New Definitions of Relevant Market and the Assault on Antitrust, 90 Colum. L. Rev. 1805, 1807 (1990) ("Knowledgeable antitrust practitioners have long known that the most important single issue in most enforcement actions-because so much depends on it-is market definition.").

${ }^{2}$ The focus of this essay is on the use of market definition to evaluate the possibility of anticompetitive seller conduct. One of the parallel market definition issues that arises when evaluating the possibility of anticompetitive conduct by buyers (the exercise of monopsony power) is addressed briefly infra note 26 . Special issues arising in the definition of innovation markets are not considered.
} 


\section{WHY DEFINE MARKETS?}

In antitrust analysis, a market is a collection of products and geographic locations, delineated as part of an inquiry aimed at making inferences about market power and anticompetitive effect. ${ }^{3}$ A market defined for this purpose is often termed a "relevant market" or an "antitrust market" in order to distinguish these markets from what business executives and consultants might define for other purposes. ${ }^{4}$

The output of the process of market definition-a collection of products and geographic locations-is used to identify the firms that participate in the market. ${ }^{5}$ That information is commonly used, among other things, to compute statistics about the size distribution of firms, usually in the form of market shares, from which inferences about market power and likely anticompetitive effect may be made.$^{6}$ For example, in assessing the reasonableness of horizontal and vertical restraints, high market shares are often thought to suggest market power, and low market shares its absence. ${ }^{7}$ Moreover, horizontal merger analysis is commonly thought to rely on a relationship between increased market concentration and higher prices. ${ }^{8}$ Some government guidelines specify safe harbors for various types of business conduct based on the market share of the firms involved. ${ }^{9}$ Courts evaluating business conduct under the antitrust laws

\footnotetext{
${ }^{3}$ For a black-letter survey of the extensive case law on market definition, see ABA Section of Antitrust law, Antitrust Law Developments 525-602 (5th ed. 2002) [hereinafter Antitrust Law Developments].

${ }^{4}$ The use of business documents to define antitrust markets is criticized in Geoffrey A. Manne \& E. Marcellus Williamson, Hot Docs vs. Cold Economics: The Use and Misuse of Business Documents, 47 Ariz. L. Rev. 609, 633-46 (2005).

${ }^{5}$ Although markets are sometimes described casually by naming the firms that participate in them, they are defined by their products and locations (and targeted buyers for a price discrimination market), not by their participants. See, e.g., U.S. Dep't of Justice \& Federal Trade Comm'n, Horizontal Merger Guidelines $\$ \S 1.12,1.22$ (1992, revised 1997) [hereinafter Merger Guidelines].

${ }^{6}$ The identification of market participants-a task that generally requires market definition-may be important to the analysis of the competitive effects of firm conduct even when market shares are not important. For example, in evaluating possible coordinated effects of merger, market participants must be identified in order to identify a maverick firm and analyze the effects of merger on its incentives, but market shares need not invariably play a role in that undertaking.

${ }^{7}$ Antitrust Law Developments, supra note 3, at 68.

${ }^{8}$ See generally Jonathan B. Baker, Mavericks, Mergers, and Exclusion: Proving Coordinated Competitive Effects Under the Antitrust Laws, 77 N.Y.U. L. REv. 135, 152-54 (2002) (survey of the economic literature relating price to market concentration).

${ }^{9}$ See, e.g., U.S. Dep't of Justice \& Federal Trade Comm'n, Statements of Antitrust Enforcement Policy in Health Care, Statements 7 \& 8 (1996) (antitrust "safety zones" based on market shares); Merger Guidelines, supra note 5, $\$ 1.51$ (general standards based on post-merger market concentration and its increase). In the Merger Guidelines, market concentration is evaluated using the Herfindahl-Hirschman Index (HHI), a statistic derived from market shares.
} 
in settings in which a per se rule does not apply commonly approach that task by defining markets and calculating market shares. ${ }^{10}$ But market definition may not be required when market power or anticompetitive effect can be demonstrated directly through means other than inference from the number, size distribution, and other characteristics of firms. ${ }^{11}$

Market definition is least useful when market shares would not be strongly probative of market power or anticompetitive effect, while direct evidence as to market power or anticompetitive effect is available and convincing. ${ }^{12}$ Market definition may make little contribution to antitrust analysis, for example, when market boundaries are difficult to draw, making the resulting market concentration statistics close to arbitrary. This may occur in industries in which firms are differentiated in product or geographic space, particularly when those spaces are densely packed with a large numbers of sellers differentiated by small degrees. ${ }^{13}$ Market definition also may not be useful when market concentration bears little relation to the economic theory by which competition would allegedly be harmed. This may occur with the loss of localized competition through merger among sellers of differentiated products. ${ }^{14}$ Yet direct evidence of anticompetitive effect or market power may be available when market definition is difficult. ${ }^{15}$

${ }^{10}$ The statutory reference in Clayton Act $\$ 7$ to a "line of commerce" and "section of the country" is frequently cited as mandating delineation of a product and geographic market, respectively, in litigation under that statute. See, e.g., ANTITrust Law DevelopMENTS, supra note 3, at 328. For an argument that Clayton Act $\$ 7$ should be interpreted to allow courts to rely primarily on direct evidence when market shares are largely uninformative as to competitive effects, see Jonathan B. Baker, Product Differentiation Through Space and Time: Some Antitrust Policy Issues, 42 Antitrust Bull. 177, 185-90 (1997).

${ }^{11}$ FTC v. Indiana Fed'n of Dentists, 476 U.S. 447, 460-61 (1986) (evaluating a Sherman Act $\$ 1$ claim under the rule of reason); Re/Max Int'l v. Realty One, Inc., 173 F.3d 995, 1018-20 (6th Cir. 1999) (monopoly power under Sherman Act $\$ 2$ established with direct evidence). Courts have been willing to rely on direct evidence to prove adverse competitive effects in Sherman Act litigation, particularly in cases involving "nearly naked" horizontal restraints, but they appear most inclined to do so when the direct evidence is consistent with what would be inferred about market power from an informal estimate of market concentration based upon a rough market definition. Andrew I. Gavil, A Comment on the Seventh Circuit's Republic Tobacco Decision: On the Utility of "Direct Evidence of Anticompetitive Effects," Antitrust, Spring 2005, at 59.

${ }^{12}$ Even when market shares, one output of the market definition process, are not strongly probative of market power or anticompetitive effect, however, another output, the identity of the sellers of close substitutes, may remain important. For example, if competitive effects are inferred from estimates of elasticities of demand, it is important to account for substitution to all close rivals but it need not be important to know market shares.

${ }^{13}$ For a discussion, see Baker, supra note 10, at 182.

${ }^{14}$ Market shares may be relevant here, however, if the distribution of buyer second choices among sellers (which identify localized competition) is strongly correlated with the distribution of buyer first choices (which are the basis for market shares). Merger Guidelines, supra note $5, \S 2.211$.

${ }^{15}$ Direct evidence of anticompetitive effect might include price increases demonstrably unrelated to benign causes, such as higher costs or improved product quality. Direct 


\section{CONCEPTUAL APPROACHES TO MARKET DEFINITION}

A number of conceptual approaches to market definition have been discussed in cases and commentary. ${ }^{16}$ The primary dispute, emphasized in this section, has concerned whether to focus solely on buyer substitution, or whether supply substitution should also be considered.

\section{A. Demand Substitution}

U.S. courts have long emphasized that markets should be defined with respect to the economic force of demand (buyer) substitution. Accordingly, courts look to the buyer's view of which products or geographic locations would be acceptable alternatives. ${ }^{17}$ This was the import of the doctrinal test announced by the Supreme Court in $d u$ Pont (Cellophane): that the market consists of goods "reasonably interchangeable by consumers for the same purposes." 18 In that monopolization decision the Court highlighted the importance of buyer substitution to market definition by equating the "reasonably interchangeable" in demand formulation with "cross-elasticity of demand between products." ${ }^{19}$ The Supreme Court confirmed that market definition turned solely on buyer substitution possibilities in a 1964 merger decision defining insulated copper conductor and insulated aluminum conductor as separate markets because of insufficient demand substitution, notwithstanding the extensive supply substitution (production flexibility) between the two that was emphasized in a dissent. ${ }^{20}$ The 1982 Department of Justice

evidence of market power (from which anticompetitive effect may be inferred) might include evidence as to demand elasticities. Two examples illustrate the connection between demand elasticities and market power. First, if a firm or group of firms raise price when demand grows less elastic, that evidence could be used to show that those sellers exercise market power. Second, if a merger among sellers of differentiated products would make the demand facing either less elastic, that evidence might be used to show that the loss of localized competition arising from merger would make it profitable for the merged firm to exercise market power by raising price for one or both firms' products.

${ }^{16}$ See generally ABA Antitrust Section, Monograph No. 12, Horizontal Mergers: LaW AND POLICY 89-130 (1986).

${ }^{17}$ Courts commonly treat both Sherman Act and Clayton Act cases as authority on market definition, regardless of whether the case involves a challenge to a merger, monopolization, or unreasonable agreement. Antitrust Law Developments, supra note 3, at 530 n.26 (citing cases).

${ }^{18}$ United States v. E.I. du Pont de Nemours \& Co., 351 U.S. 377, 395 (1956) (Cellophane). In a similar formulation, the Court also stated that the "market is composed of products that have reasonable interchangeability for the purposes for which they are producedprice, use and qualities considered." Id. at 404. The so-called Cellophane fallacy is discussed in Part V.B below.

${ }^{19} I d$. at 400 .

${ }^{20}$ Compare United States v. Aluminum Co. of Am., 377 U.S. 271, $276-77$ (1964) (Rome Cable) (majority defines market based on demand substitution), with id. at 285 (dissent favors broader market based on both supply and demand substitution). 
Merger Guidelines followed these Supreme Court decisions by focusing on buyer substitution, and refined the approach by suggesting a conceptual metric, the hypothetical monopolist test, for judging how much buyer substitution would be sufficient to preclude a proposed market definition. This approach continues to be applied by the enforcement agencies, with only minor refinements since $1982 .{ }^{21}$

Specifically, the current Horizontal Merger Guidelines define a market as a collection of products or services, and a geographic region, that would form a valuable monopoly. ${ }^{22}$ If it would be unprofitable for a hypothetical monopolist of a group of products within a region to raise price by a small but significant and nontransitory amount ${ }^{23}$ because buyers would substitute to other products or locations, then the candidate (provisional) market is too small and must be expanded. ${ }^{24}$ The Merger Guidelines suggest that the candidate market expand to include products or locations to which the most buyer substitution would occur, and the hypothetical monopolist question then be asked again. ${ }^{25}$ Part III below discusses the implementation of this conceptual approach to market definition. ${ }^{26}$

\section{B. Supply Substitution}

Since the mid-1970s, some U.S. courts have also employed market definition to account for a second economic force, supply substitution. ${ }^{27}$

${ }^{21}$ One change is discussed infra note 66.

${ }^{22}$ For a discussion of the history and application of the hypothetical monopolist test for market definition, see generally Gregory J. Werden, Market Delineation and the Justice Department's Merger Guidelines, 1983 DukE L.J. 514 (1983); Gregory J. Werden, The History of Antitrust Market Delineation, 76 MarQ. L. Rev. 123 (1992); Gregory J. Werden, The 1982 Merger Guidelines and the Ascent of the Hypothetical Monopolist Paradigm, 71 Antitrust L.J. 253 (2003) [hereinafter The 1982 Merger Guidelines].

${ }^{23}$ The Merger Guidelines' reference to a "small but significant and non-transitory" increase in price is often abbreviated as SSNIP (pronounced "snip").

${ }^{24}$ The useful term "candidate market" was originated by Greg Werden.

${ }^{25}$ For example, product markets are defined through "successive iterations" of the price increase test. Merger Guidelines, supra note $5, \S 1.11$.

${ }^{26}$ This essay addresses settings in which the allegation concerns the exercise of market power by sellers. In monopsony cases, in which the allegation concerns the exercise of market power by buyers, markets would be defined analogously with respect to the economic force of seller substitution. The "hypothetical monopsonist" issue in market definition in such cases is whether the collective exercise of market power by the buyers of a group of products within a region, which depresses the prices paid to sellers through a reduction in purchases, would be made unprofitable by seller decisions to deal instead with other buyers or to cease participation in the market.

${ }^{27}$ See generally Jonathan B. Baker, The Antitrust Analysis of Hospital Mergers and the Transformation of the Hospital Industry, 51 Law \& Contemp. Probs. 93, 101-02 \& n.42 (1988); Antitrust Law Developments, supra note 3, at 553-56. 
These courts expand markets even though a group of products and locations would appear to form a valuable monopoly after accounting for buyer substitution to outside alternatives, when the monopoly would likely not be profitable after also accounting for the incentive of outside sellers to begin producing and selling within the candidate market. ${ }^{28}$ The Merger Guidelines instead account for supply substitution in steps of merger analysis that take place after market definition, either in the identification of market participants or the evaluation of entry conditions..$^{29}$ Accordingly, the argument as to whether to incorporate supply substitution in market definition is not about whether to recognize this economic force in antitrust analysis; it is over at what stage of the analytical process to do so.

The approach taken by the Merger Guidelines is preferable because it can be both difficult and confusing to ask one analytical step, market definition, to account for two economic forces, demand and supply substitution. ${ }^{30}$ These difficulties will be illustrated with an extended example involving a hypothetical merger.

Suppose that a court is considering a prospective merger between sellers of insulated copper conductor, used to carry electric current. Suppose further that insulated aluminum conductor can also carry electric current, but that the physical properties of these alternatives and their prices dictate that copper conductor is the clear choice for underground wiring while aluminum conductor is the clear choice for above-ground wiring. Under such circumstances, buyers of copper conductor would not substitute to aluminum conductor even if the price of copper conductor were to increase substantially. From a demand-side perspective, therefore, insulated copper conductor constitutes an antitrust product market.

\footnotetext{
${ }^{28}$ Accord Richard A. Posner, Antitrust Law 148 (2d ed. 2001).

${ }^{29}$ Federal Trade Comm'n \& U.S. Dep't of Justice, Commentary on the Horizontal Merger Guidelines 5 (2006) [hereinafter Guidelines Commentary].

${ }^{30}$ For a similar reason, the significance for competitive effects of demand complementarities should not be accounted for in the market definition step of the analytical process. Contra, David S. Evans \& Michael D. Noel, Analyzing Market Definition and Power in Multisided Platform Markets (Working Paper Oct. 2005), available at http://ssrn.com/abstract= 835504 (proposing to account for demand complementarities associated with "two-sided" businesses through market definition); Renata B. Hesse \& Joshua H. Soven, Defining Relevant Product Markets in Electronic Payment Network Antitrust Cases, 73 AnTitrust L.J. 709, 728,732 (2006) (explaining that the Justice Department proposed to account for reactions by the other side of a two-sided market when defining the product markets in a recent case involving electronic payment systems). Rather, the significance of demand complementarities should be accounted for in the later analysis of competitive effects. See Baker, supra note 27 , at 123-40 (discussing competitive significance of the possibility that merging firms also sell demand complements).
} 
Now suppose further that many producers of insulated aluminum conductor could quickly and inexpensively switch their production capacity to the manufacture of copper conductor, and would profitably do so in large amounts if the price of copper conductor were to rise slightly. If so much capacity would be diverted in this way as to prevent the price of copper conductor from increasing for long, a merger among producers of copper conductor would likely not harm competition. This conclusion is readily reached when markets are defined based solely on demand substitution: under the Merger Guidelines, the product market would be limited to copper conductor, but the aluminum conductor producers would be recognized as participants in that market and assigned market shares reflecting the capacity they would profitably divert into the copper conductor market (even though they are not presently producing copper conductor) ${ }^{31}$ When supply substitution is accounted for in this way, the merging firms' market shares will be small, demonstrating that the merger would likely not harm competition.

A similar conclusion as to competitive effects could also be reached by accounting for supply substitution in market definition: expanding the market to include aluminum conductor as well as copper conductor. In this expanded market, the merging firms' market shares will again be small. But a number of conceptual and practical pitfalls must be avoided before it would be appropriate to reach the conclusion that the merger would not likely harm competition if considerations of supply substitution are incorporated into the market definition step of the analysis.

To see the first problem, suppose that there are two types of firms producing aluminum conductor, employing different production processes. Only type 1 aluminum conductor firms could quickly and inexpensively shift to producing copper conductor. If there are many type 2 aluminum conductor firms, which cannot readily switch to copper conductor, but relatively few type 1 aluminum conductor firms, which can, and if the market is broadened to include all conductors, the resulting low market shares may mislead by improperly suggesting that the merger of copper conductor firms would be unlikely to create a competitive problem. This problem is readily avoided when markets are defined with respect to demand substitution only, as only the divertible capacity of

\footnotetext{
${ }^{31}$ Any reasonable method of analyzing the competitive effects of this hypothetical merger would need to account for the extent to which aluminum conductor capacity would profitably be diverted to copper conductor production in the event that the price of copper conductor were to rise. Under the Merger Guidelines, that analysis would take place in assigning market shares rather than in market definition.
} 
aluminum conductor producers with production flexibility would then be viewed as devoted to the copper conductor market.

Second, suppose that all aluminum conductor firms could rapidly switch to copper conductor production but some would not find it profitable to do so because they would have to break long-term highmargin contracts with buyers of aluminum conductor. Under the demand substitution approach of the Horizontal Merger Guidelines, this problem would also sensibly be addressed by assigning low market shares to firms that lack substantial divertible capacity. But under a supply substitution approach, all current sales or capacity of aluminum conductor firms would be included in computing market shares, leading to market shares for the merging copper conductor producers that would likely understate the competitive significance of that merger. ${ }^{32}$

Third, suppose that another product, insulated nickel conductor, is a close demand substitute for aluminum conductor but not a close substitute for copper conductor. If so, it could be difficult in practice to defend a product market that includes aluminum conductor but excludes nickel conductor. A conscientious court expanding the product market beyond copper conductor on the ground that aluminum conductor is a good supply substitute may be hard-pressed to define anything short of an all-conductor market, including copper, aluminum, and nickel conductor. The result, again, would be to reduce market shares for the merging copper producers relative to what they would have been in a copper conductor market, defined based solely on demand substitution and, thus, lead to shares that likely understate the competitive significance of the merger.

Fourth, suppose that aluminum conductor is a supply substitute for copper conductor, and the market is expanded in consequence to include all conductors. Let copper conductor be a larger market segment than aluminum conductor, so that the market shares of the merging firms remain high in the broader market. Suppose further that entry is easy into the aluminum conductor segment using a technology different from that of the incumbent aluminum conductor firms, and that any resulting entrants would be unable to shift easily into the production of copper conductor. Easy entry into the aluminum conductor segment may well fail to solve the competitive problem arising from a merger of

${ }^{32}$ The possible absence of a competitive constraint from nonmerging copper conductor producers unable to expand output inexpensively would be addressed in the analysis of competitive effects, regardless of whether markets are defined from a pure demand-side perspective or whether supply substitution is incorporated into that process. 
copper conductor producers. ${ }^{33}$ If the market is defined as all conductors, it would be easy to miss this point, and improperly conclude that there is no competitive problem from a merger of copper conductor firms.

Fifth, suppose that the aluminum conductor production process is similar, but not identical, to the copper conductor process. As a result, copper conductor made by aluminum conductor producers is not a perfect substitute for copper conductor made by firms specializing in that product. Suppose further that the difference is not important for one group of copper conductor buyers-they would be happy to substitute copper conductor made by the aluminum conductor firms-but that the difference matters greatly to a second group of copper conductor buyers, which would not switch to the conductor produced by those aluminum conductor firms that have shifted production to copper conductor. Under these circumstances, the ability of supply substitutors to prevent a copper conductor price increase after merger turns on whether most customers are in the first group, happy to substitute copper conductor made by aluminum producers, or whether most are in the second group, unwilling to do so. A demand-side market definition limited to copper conductor facilitates close analysis of this question. But if markets are defined according to supply substitution, it is too easy to presume without analysis that all customers would be willing to accept copper conductor manufactured by aluminum conductor firms. Doing so could again reduce market shares for the merging copper producers relative to what they would have been in a copper conductor market defined solely based on demand substitution and, thus, lead to shares that likely understate the competitive significance of the merger. ${ }^{34}$

\footnotetext{
${ }^{33}$ Incumbent aluminum conductor producers may switch into copper conductor production, and new entrants may begin to produce aluminum conductor. But this supply response may not be sufficient to prevent an increase in copper conductor prices because of the relatively small increase in copper conductor output.

${ }^{34}$ This kind of problem is more than a theoretical concern: a similar analytical step appears to have been skipped improperly by an expert antitrust tribunal evaluating exclusionary conduct allegations in the Seventh Circuit's decision in Menasha Corp. v. News America Marketing In-Store, Inc., 354 F.3d 661 (7th Cir. 2004) (Easterbrook, J.). The principal question in the Menasha case was whether the product market should be limited to atshelf coupon dispensers (attached to grocery store shelves), giving defendants a large market share. The circuit court expanded the market to reflect supply expansion by providers of "signs and placards, end caps (product racks at the end of aisles), sales, coupons included on (or in) the product's package, coupons distributed at the checkout counter, and ... the traditional coupons distributed by mail or newspaper." Id. at 664 . In the resulting broader market, defendants apparently had a low market share. But the court never asked whether buyers (product manufacturers) would in fact substitute these forms of promotion for at-shelf dispensers in response to higher dispenser prices, and would do so in sufficient numbers to prevent any exercise of market power among sellers of at-shelf dispensers.
} 
These problems could, in theory, be addressed within a broad product market defined according to both supply and demand substitution, with careful analysis. But in some of the examples involving copper and aluminum conductor discussed above, one step of that analysis would necessarily involve understanding buyer substitution-the very analysis that must be conducted to define markets based purely on demand substitution. In the remaining examples, defining markets based solely on demand substitution is not necessary to address the issue, but it facilitates careful analysis of the scope and profitability of supply substitution.

In practice, courts rarely employ supply substitution to help define markets in the context of merger analysis ${ }^{35}$ deviation from an exclusive demand-side focus is more likely to occur when courts define markets under the Sherman Act. One reason may be that outside of merger review, courts have historically been reluctant to undertake the balancing of procompetitive and anticompetitive effects required by the unstructured rule of reason in horizontal agreement cases, or arguably required to identify exclusionary conduct in monopolization cases. ${ }^{36}$ Adjusting the definition of the market allows courts to account for supply substitution without opening the door to a wide-ranging competitive inquiry. For example, in analyzing an agreement among rivals, expanding the market to show lack of market power may be a tempting analytical approach when rivals would readily undermine the exercise of that power by increasing supply, as it may allow a court to dismiss a case using a "quick look to exonerate." ${ }^{37}$ But the better approach, as described above, is to account for only one economic force, demand substitution, in the market definition stage of the competitive effects analysis, and to account for supply substitution in one or more other steps of the analysis (identifying market participants, analyzing competitive effects, and evaluating entry conditions). This alternative would help avoid analytical errors and still permit a court to dismiss the case with dispatch if that outcome is appropriate.

\section{ASSESSING DEMAND SUBSTITUTION IN PRACTICE}

Market definition for antitrust purposes requires, first and foremost, an assessment of the magnitude of the economic force of buyer substitution. This is an economic question shaped by the demands of the legal frame-

\footnotetext{
35 The influence of the demand-side focus of the Merger Guidelines on the courts is described in Werden, The 1982 Merger Guidelines, supra note 22.

${ }^{36}$ Antitrust Law Developments, supra note 3, at 77.

${ }^{37}$ Andrew I. Gavil, William E. Kovacic \& Jonathan B. Baker, Antitrust Law in Perspective: Cases, Concepts and Problems in Competition Policy 198-99 (2002).
} 
work for competition policy. Accordingly, there is no reason to expect that the concept of market employed by business executives when discussing issues of business strategy or marketing, whether in testimony or documents prepared for business purposes, would be the same as the concept of an "antitrust market" or "relevant market" defined for the purpose of antitrust analysis. The informed views of executives as to the nature and magnitude of likely buyer substitution are relevant to antitrust market delineation, as discussed below, but the specifications of markets they adopt for business purposes unrelated to antitrust analysis should not control the definition of the market for antitrust purposes.

\section{A. Types of Evidence as to Buyer Substitution}

Evidence as to likely buyer substitution patterns in the event of an increase in price-the central economic issue at stake in market definition-can be grouped into five categories: past buyer responses; buyer surveys; product characteristics; seller conduct; and views of industry experts. Within each category, evidence may be quantitative or qualitiative.

The first category involves the response of buyers to changes in relative prices in the past. Such evidence can be quantitative and systematic, as with econometric estimates of demand elasticities, ${ }^{38}$ or econometric analyses of natural experiments involving a change in market structure. ${ }^{39}$ Evidence as to buyer responses can also be anecdotal. A firm's marketing executives may be able to report on the results of an experiment with a price increase, or recall that price rose following an increase in marginal cost. The executives may have an understanding of which rival firms also raised price (effectively specifying the participants in a candidate market), whether those firms collectively lost share following a price increase, and, if so, which rivals not increasing price benefited the most from buyer substitution. If there is good reason to believe that the price or cost changes did not result from a shift in demand, ${ }^{40}$ such anecdotes

\footnotetext{
38 The demand elasticity at issue in market definition is an own-price elasticity, as discussed below in notes 49 and 134. Cross-price elasticities of demand are relevant because they can be used to identify the next-best substitutes that should be included if the candidate market is expanded and because of the mathematical relationship between own- and cross-elasticities set forth below in note 134 .

${ }^{39}$ Methods of inferring the magnitude of buyer substitution from natural experiments involving a change in market structure have been used to analyze the unilateral competitive effects of merger among sellers of differentiated products. Jonathan B. Baker, Econometric Analysis in FTC v. Staples, 18 J. Pub. Pol'y \& MктG. 11 (1999). These methods are equally appropriate for the analysis of market definition, as buyer substitution is the central economic force at issue in both inquiries.

${ }^{40}$ This is an example of what is termed in econometrics the problem of identification. See generally Jonathan B. Baker \& Timothy F. Bresnahan, Economic Evidence in Antitrust:
} 
could provide valuable informal evidence as to the extent of buyer substitution and the identity of next-best substitutes that should be included in the market if the candidate market is expanded.

Second, buyer surveys may provide evidence as to the likely response of buyers to price changes. Retail customers could be sampled using a carefully constructed survey instrument, for example. ${ }^{41}$ Surveys could also be informal, based on customer interviews. ${ }^{42}$ If there is some basis for concluding that the customer views are informed and representative and that they account for a reasonable fraction of the relevant business, even an informal survey may provide a reliable guide to likely buyer substitution patterns. ${ }^{43}$ Under some circumstances, moreover, bidding records could similarly be treated as a type of customer survey and relied upon to identify how buyers would likely respond to a price increase.

Third, likely buyer substitution patterns in response to a price increase may be inferred from information about the characteristics of products and geographic locations known to matter to buyers (including the distribution of switching costs across buyers). Quantitative methods of inferring the distribution of the valuations buyers place on unobservable product characteristics from data on market shares and buyer characteristics can be employed for this purpose. But less formal inferences may also be useful. For example, information about the geographic distribution of customers and shipping costs can help assess the likelihood of buyer substitution to more distant locations from those in a candidate market and so bear on geographic market definition. ${ }^{44}$

Defining Markets and Measuring Market Power (Stanford Law and Economics Olin Working Paper No. 328, Sept. 2006), available at http://ssrn.com/abstract=931225.

${ }^{41}$ See, e.g., Jonathan B. Baker \& Daniel L. Rubinfeld, Empirical Methods in Antitrust Litigation: Review and Critique, 1 AM. L. \& ECON. REv. 386, 424-27 (1999) (discussing conjoint survey methods).

${ }^{42}$ When investigating a merger involving producers of an intermediate good sold to a limited number of industrial buyers, the enforcement agencies frequently seek to interview all the buyers about their willingness to substitute away from the product in the event of a price increase.

${ }^{43}$ The reliability of customer statements unsupported by analysis as to buyer inability to substitute away from the products in a candidate market in response to a price increase was questioned in United States v. Oracle Corp., 331 F. Supp. 2d 1098, 1131 (N.D. Cal. 2004). The court refused to consider customer views when defining markets and evaluating the unilateral effects of merger on the ground that those views were not based on an expensive new analysis that would not routinely be undertaken in the ordinary course of business. This conclusion takes an overly narrow view of the possible evidentiary bases for crediting customer views as informed and reliable.

${ }^{44}$ Similarly, informal analysis of switching costs may bear on product market definition. See, e.g., Bayer AG, C-No. 4049, 2002 WL 1151015 (FTC May 30, 2002) Complaint $\uparrow 11$ (defining a market for "new generation" chemical insecticides based in part on an informal switching costs analysis of the advantages to buyers of new-generation products relative to older insecticides). 
The remaining two categories of evidence as to demand substitution are derivative of the first three, but they rely on informed actors other than buyers to assess and integrate the direct evidence as to buyer substitution patterns. The fourth type of evidence as to buyer substitution patterns infers them from the conduct of industry participants-or more precisely uncovers how buyer substitution is understood by sellers. For example, evidence about the extent to which firms monitor and respond to the price changes and new product introductions of rival sellers, and about the products and locations of the rivals that have their greatest attention, is commonly employed as a guide to the products and locations where buyer substitution is the most likely. ${ }^{45}$ If the sellers are in a position to learn about buyer substitution patterns through the methods previously described-based on their observation of buyer responses to past price changes, discussions with customers, and familiarity with buyer and product characteristics - and if they are willing to base business decisions on that information, this evidence may be probative with respect to antitrust market definition. ${ }^{46}$

Fifth, the views of industry experts-including, for example, industry consultants, trade press reporters, trade association executives, former industry executives, or sellers of complementary products-may be useful in judging likely buyer substitution responses to prices. The reliability of this evidence can be assessed by examining, among other things, whether the experts are in a position to gather direct information about buyers and whether they base costly business decisions on that information.

Which of these types of evidence as to the extent of buyer substitution is the most probative will vary from case to case. ${ }^{47}$ Direct evidence from buyers is not inherently more or less reliable or persuasive than inference from information from seller conduct or the distribution of buyer characteristics.

\footnotetext{
${ }^{45}$ The probative value of inferences about the extent of buyer substitution from another aspect of seller behavior, the way sellers set prices relative to costs, is discussed in connection with critical loss analysis in Part IV.C below.

${ }^{46}$ But seller documents can raise issues of interpretation. For example, if competitors are numerous, sellers may find it cost-effective to sample representative rivals rather than monitoring all of the rivals that matter to them. Similarly, sellers may devote more attention to monitoring actual rivals than potential rivals, even if the latter also help constrain seller pricing. Also references in seller documents to the "market" may not be useful for antitrust market definition when executives or consultants define markets for non-antitrust purposes using criteria that differ from those that apply to antitrust market definition.

${ }^{47}$ For additional discussion, see Baker \& Bresnahan, supra note 40.
} 


\section{B. How Much Buyer Substitution Is Enough?}

In principle, the magnitude of likely buyer substitution in the event of a price increase must be compared with the magnitude of price-cost margins in order to determine whether that price increase would be profitable were firms to act collectively as a single seller and, thus, whether to define a market. The conceptual issues involved in making this comparison will be set forth first, after which some practical implications will be discussed.

The profitability of a small price increase by a hypothetical monopolist turns on a tradeoff: price-cost margins increase to those buyers who continue to purchase (notwithstanding the higher price), but the hypothetical monopolist loses the entire price-cost margin it would previously have received from those buyers who are led by the higher price to substitute away from its products or locations. ${ }^{48}$ Accordingly, if margins are small, the hypothetical monopolist may find a price increase profitable (absent massive buyer substitution outside the candidate market), and the candidate market might be accepted as an antitrust market. If margins are large, the costs of raising price may exceed the gains (unless buyers are extremely unresponsive to increases in price), and the candidate market may need to be expanded in order to define an antitrust market. In this way, the magnitude of buyer substitution-the answer to the question of how much substitution is enough to define a marketis in principle calibrated by price-cost margins. ${ }^{49}$

This comparison is better viewed as a conceptual guide than as an algorithm for implementation. The particulars of any formula would need to account for various features of the market, such as whether firms sell multiple products, differentiated products, or discriminate in

\footnotetext{
${ }^{48}$ This paragraph simply makes a conceptual point and should not be regarded as endorsing the controversial "critical loss" approach to market definition, which is discussed in Part IV.C below.

${ }^{49}$ The first-order condition for profit maximization by a single-product monopolist that does not discriminate among buyers can be written as equating the absolute value of the inverse of the elasticity of the demand function facing the monopolist with the seller's Lerner Index of price-cost margin (price less marginal cost, as a fraction of price), or $1 / \varepsilon=\mathrm{L}$. In consequence, a price increase is profitable for a hypothetical monopolist if and only if the inverse elasticity of demand exceeds the Lerner Index $(1 / \varepsilon>\mathrm{L})$. This equation (or related formulae) can, in theory, be used to define markets by simulating whether a hypothetical monopolist would raise price, by estimating and comparing the two sides of the inequality. See generally Gregory J. Werden, Demand Elasticities in Antitrust Analysis, 66 Antitrust L.J. 363 (1998). It is worth noting that changes in the Lerner Index over time (for example, an increase in price-cost margins after the alleged violation occurred) are not informative as to whether current margins correspond to the elasticity of firm demand without information about the way the distribution of buyer willingness to pay, and thus the demand elasticity, changed over the same time period.
} 
price. ${ }^{50}$ Even when the magnitude of buyer substitution can be assessed reliably ${ }^{51}$ using the five types of evidence set forth above,,$^{52}$ the relevant price-cost margins, based on economists' rather than accountants' definitions, may be hard to assess. Under some circumstances, for example, there will be more than one price. Moreover marginal cost, the cost in the comparison, is often difficult to infer from accounting data. ${ }^{53}$ Notwithstanding these problems, this framework is sometimes employed as the basis for simple simulation modeling of the profitability of a hypothetical price increase and thus as the basis for a controversial quantitative approach to market definition termed "critical elasticity" or "critical loss" analysis. ${ }^{54}$

The process of market definition involves judgments as to "matters of degree" that can at times be "extremely difficult to measure." ${ }^{55}$ Yet, precise calibration based upon a close analysis of price-cost margins is not always necessary. For example, if buyer substitution would likely be extensive in response to a small price increase among sellers in a candidate market-if demand is relatively elastic-the hypothesized price

${ }^{50}$ Complications in defining markets such as these are considered in one industry setting in Randy Brenkers \& Frank Verboven, Market Definition with Differentiated Products-Lessons from the Car Market (Centre for Economic Policy Research Discussion Paper No. 5249, Sept. 2005), available at http://www.cepr.org/pubs/dps/DP5249.asp.

${ }^{51}$ For example, it may be difficult to determine how much a hypothetical monopolist would raise price, and, thus, whether price would rise by more than the SSNIP, if there is reason to believe that the elasticity of demand varies as price increases. This possibility is highlighted in Luke M. Froeb \& Gregory J. Werden, Residual Demand Estimation for Market Delineation: Complications and Limitations, 6 REv. Indus. ORG. 33 (1991). This issue is discussed below in connection with the Cellophane fallacy in Part V.B, and in connection with critical loss analysis in Part IV.C.

${ }^{52}$ When using the relationship $1 / \varepsilon=\mathrm{L}$ to evaluate a proposed market definition, the demand elasticity parameter summarizes all the available evidence as to buyer substitution. There is no presumption that it is estimated econometrically, though it could be.

${ }^{53}$ Marginal cost is not necessarily the price that would obtain absent anticompetitive conduct, which for this purpose may be understood as the competitive price. The competitive price could exceed marginal cost, for example, if products or locations are differentiated, firms engage in competitive price discrimination, or the sellers engage in oligopoly conduct without reaching an agreement or otherwise violating the antitrust laws. If the competitive price were known, that would permit direct proof of the existence or absence of market power, obviating the need for market definition.

${ }^{54}$ See discussion infra Part IV.C. Used in this way, this framework has similar strengths and weaknesses as simulation modeling generally. For example, it can help develop intuition and judgment as to market definition by providing a metric for understanding the significance of demand elasticities, and it can help identify areas where collection of additional information would be useful in pinning down whether a proposed market should be defined. But it may also incorporate a number of assumptions that are difficult to test or modify, making the results unhelpful or misleading. Particular difficulties associated with making inferences as to the magnitude of buyer substitution from price-cost margins are addressed below in Part IV.C.

${ }^{55}$ Pitofsky, supra note 1 , at 1807. 
increase is unlikely to be profitable so the candidate market should be expanded. That is, absent evidence that demand becomes substantially less elastic as price rises, or that marginal costs rise sharply with output in the neighborhood of the prevailing price, it may well be reasonable to conclude simply from observing relatively elastic demand for the products and locations in a candidate market that a hypothetical monopolist would not find it profitable to raise price, without undertaking a careful comparison of demand elasticities and price-cost margins. Similarly, if buyer substitution would not be extensive, a price rise would likely be profitable and the candidate market would likely qualify as an antitrust market.

\section{Applying the Algorithm of the Horizontal Merger Guidelines}

The Horizontal Merger Guidelines clarify the process of market definition by specifying a theoretical algorithm for implementing the hypothetical monopolist test. ${ }^{56}$ Under that algorithm, the analyst specifies as an initial candidate market each narrowly defined product and location at which it is produced or sold for each merging firm. A candidate market constitutes a relevant antitrust market if a hypothetical monopolist pursuing maximum profits would raise the price of some or all products, at some or all locations, by a small but significant and nontransitory (SSNIP) amount ${ }^{57}$ (holding constant the terms of sale of all other products), relative to the prices that would prevail but-for the merger under review. If the hypothetical monopolist would not find a SSNIP profitable, the candidate market is expanded by adding the next-best substitute, the new candidate market tested to determine whether it constitutes a relevant antitrust market, and so on. ${ }^{58}$ Each starting point (each initial candidate market) could, in principle, lead to a different

\footnotetext{
56 "There is little question that relevant market definition was a more coherent exercise during the 1980s than in previous decades, and that can be attributed in part to the orderly, intellectual approach of the Guidelines." Id. at 1808. See also Gregory J. Werden, Market Delineation Algorithms Based on the Hypothetical Monopolist Paradigm (Working Paper July 27, 2002), available at http://papers.ssrn.com/sol3/papers.cfm?abstract_id=327282 (proposing a formal mathematical statement of the algorithm).

${ }^{57}$ The Merger Guidelines suggest considering in most contexts a price increase of $5 \%$ lasting for the foreseeable future. Merger Guidelines, supra note $5, \S 1.11$. The enforcement agencies frequently instead employ a $10 \%$ figure in this role. Robert Pitofsky has criticized the use of the higher figure as encouraging overinclusive market definitions. Pitofsky, supra note 1, at 1823-24.

${ }^{58}$ Cf. Malcolm B. Coate \& Jeffrey H. Fischer, A Practical Guide to the Hypothetical Monopolist Test for Market Definition 6 (Potomac Papers in Law and Economics Working Paper 06-01, Oct. 2006), available at http://ssrn.com/abstract=940667 ("If the [hypothetical] price increase is profitable, then the gap [in the chain of substitutes] is material and a relevant market is defined. If not, simply find another gap and test again.").
} 
relevant market in which the possibility of anticompetitive effects could be analyzed, though the same outcome could in practice arise from multiple starting points.

Three implementation issues raised by this theoretical algorithm are discussed below. Special problems in the application of the algorithm to retrospective harm cases and to exclusion cases are deferred to Parts $\mathrm{V}$ and VI, respectively.

\section{Specifying the Initial Product or Region}

Where should the process of market definition begin? Suppose a product market must be defined in order to analyze the competitive effects of conduct undertaken by Coca-Cola. Perhaps Coke is acquiring another firm, is accused of harming competition by excluding some rivals, or has introduced a practice, on its own or by agreement with other firms, said to facilitate coordination among rivals. ${ }^{59}$ Among other products, Coca-Cola sells regular Coca-Cola (a cola-flavored soft drink), Diet Coke (sugar-free), caffeine-free Coca-Cola, caffeine-free Diet Coke, Sprite (a lemon-lime flavored soft drink), and Dasani (bottled water). Moreover, these products are sold in a variety of package types, including bottles and cans in a range of sizes. In principle, one might specify each finely distinguished product-for example, caffeine-free Diet Coke in 12 oz. cans-as a candidate market, thus beginning the analysis with a large number of candidate markets. If caffeine-free Diet Coke in 12 oz. cans were not a market, the candidate market would be expanded to the next best substitute-perhaps caffeine-free Diet Coke in bottles, perhaps caffeine-free Coca-Cola, perhaps Diet Coke (caffeinated), or perhaps caffeine-free Diet Pepsi (sold by a competitor) - and the hypothetical monopolist test applied again.

In practice, market definition would likely begin with a larger aggregate-all colas, all soft drinks, or all beverages, for example. ${ }^{60}$ If disaggregated information about buyer substitution patterns is available and the outcome turns on the starting point, a more finely defined product might be an appropriate place to begin the analysis. ${ }^{61} \mathrm{But}$ it

\footnotetext{
${ }^{59}$ Other aspects of the approach to market definition may differ across these settings, particularly depending on whether the alleged harmful conduct was prospective or retrospective, as discussed infra in Parts V and VI.

${ }^{60}$ The Merger Guidelines' approach of starting with finely defined candidate markets and expanding them is often difficult to apply in practice, in part, because it is often impossible to understand buyer substitution patterns (including the elasticity of candidate product demand and the identification of next-best substitutes) for finely defined products with sufficient precision to make the necessary judgments.

${ }^{61}$ In principle, the starting point could be disaggregated more finely than, for example, regular Coke sold in a $12 \mathrm{oz}$. can. One could view regular Coke as the combination of
} 
would almost never be appropriate to begin by disaggregating more narrowly than the specific products that are purchased by the buyers alleged to have been harmed by the conduct under review. ${ }^{62}$

\section{SSNIP with Other Terms of Sale Held Constant}

The conceptual experiment that identifies buyer substitution patterns presumes that the price for products and locations in the candidate market would increase by a small amount, while prices of all products and locations outside that candidate market do not increase in price. The small price increase is commonly taken to be 5 percent (the figure suggested in the Horizontal Merger Guidelines) or 10 percent (an alternative frequently adopted by the enforcement agencies), though it could be higher or lower. ${ }^{63}$ This figure is not a tolerance level for anticompetitive price increases; it is merely an arbitrary benchmark for assessing buyer substitution. ${ }^{64}$ The conceptual experiment presumes that the hypo-

flavored syrup manufactured by the Coca-Cola Company, along with complementary products purchased by Coca-Cola, including bottling services, distribution services, and marketing. Similarly, one might ask, why begin market definition in a case involving automobiles with a specific brand and model of car? After all, the car purchased by a retail customer can be disaggregated further: it combines a chassis, tires, an engine, and a radio, among other things, along with the distribution and marketing services provided by a dealer. Shouldn't market definition begin with each of these? Viewed this way, virtually all products can be thought of as combinations of demand complements (which have presumably been bundled or assembled because sellers can do so more cheaply than can buyers). Hence, this perspective would require that market definition commence with numerous candidate markets (e.g., the chassis, tires, engine, etc.) in any individual case. This perspective is not appropriate to antitrust market definition, however, because it is not tied to the buyers who would be harmed by the alleged antitrust violation and so conflicts with the demand-substitution focus of market definition.

${ }^{62}$ Products should generally not be disaggregated more finely than what is purchased by the particular buyers alleged to have been harmed by the conduct under review. $C f$. Werden, supra note 56, at 25 (observing that market delineation algorithms can be applied to bundles of products that arise as a result of "technological integration, combined packaging, or contractual tying"). An exception might arise if a plaintiff alleged that the conduct under review harmed competition by leading defendants to alter the attributes of the products they sell (for example, in order to raise entry barriers or discriminate in price in a manner that harms consumers). Other examples of the importance of relating market definition to the allegations in the case are considered infra Parts V and VI.

${ }^{63}$ Some of the five types of evidence as to buyer substitution discussed in Part III.A. above can be used to calibrate the magnitude of the likely buyer response to a specific percentage price increase more closely than can others. For example, evidence as to which rival products are monitored and responded to by sellers may not correspond readily to a particular percentage price increase or suggest a precise percentage for the buyer response, yet this evidence could nevertheless be strongly probative as to market definition. The quantitative aspects of the market definition approach of the Merger Guidelines provide conceptual clarity, but they do not mandate a systematic preference for quantitative evidence.

${ }^{64}$ The scope of the market defined using this algorthim could vary with the size of the SSNIP chosen. Other reasons multiple markets could be defined from a single starting point are discussed below in the next note and in Part III.C.3. Moreover, the actual price

74 Antitrust Law Journal No. 1 (2007). Copyright 2007 American Bar Association. Reproduced by permission. All rights reserved. This information or any portion thereof may not be copied or disseminated in any form or by any means or downloaded or stored in an electronic database or retrieval system without the express written consent of the American Bar Association. 
thetical monopolist would reduce competition on the price dimension; this assumption is commonly useful to frame the process of market definition even if market power would be exercised on multiple dimensions, but there is no bar, in principle, to basing the market definition algorithm on a small reduction in competition on some nonprice dimension if that alternative is more convenient. ${ }^{65}$

The assumption that the price of only the products and locations in the candidate market changes, introduced in the 1992 revisions to the Horizontal Merger Guidelines, is intended to focus the market definition exercise on the economic force of buyer substitution. The possible response of sellers of products or at locations outside the candidate market, whether those outside firms compete more or less aggressively in response to a small price increase, and whether they would find it profitable or feasible to increase their own output, is left for other steps of competitive effects analysis. ${ }^{6}{ }^{6}$

\footnotetext{
increase thought likely to occur as a result of challenged conduct could be greater than or less than the benchmark SSNIP used for market definition. In theory, harm to competition could be found even if only a small price increase is thought likely. In practice, the difficulty of distinguishing a small number from zero with the available evidence, the Merger Guidelines' safe harbors (which discourage government enforcement when market concentration is low even if some harm to competition could be demonstrated), and the resource constraints facing government enforcers and other plaintiffs, combine to make unlikely a challenge to a merger that would increase price by a minute amount.

${ }^{65}$ In the context of implementing the conceptual experiment for market definition, a price increase is simply a measurable proxy for any small change (whether on a price or nonprice dimension) that makes what is sold in the candidate market less attractive to buyers. Cf. Michael L. Katz \& Howard A. Shelanski, Mergers and Innovation, 74 AnTitrust L.J. 1, 36 (2007) ("What is needed is a careful analysis of what constitutes a real price increase in the face of cost and product changes."). If market definition is based on a small reduction on a nonprice quality dimension, the resulting market could in theory differ from what would result if the conceptual experiment involves a small increase in price. This could happen if buyers respond differently to small changes in product attributes than to small changes in price or if the product or location constituting the nextbest substitute (the basis for expanding a candidate market) differ as the conceptual experiment changes. This observation provides another reason why the process of market definition could result in multiple markets within which the possibility of anticompetitive effects could be analyzed.

${ }^{66}$ Hence, market definition turns on the own-price elasticity of structural demand. Before 1992, market definition was generally thought to turn on the own-price elasticity of residual demand. The residual demand elasticity, which incorporates supply responses as well as demand responses, remains relevant to the assessment of competitive effects of the conduct under review (possibly making market definition and evidence involving the structural demand elasticity unnecessary). For a recent effort to define markets using an approach that accounts for both demand and supply responses, see Mark Ivaldi \& Szabolcs Lörincz, A Full Equilibrium Relevant Market Test: Application to Computer Servers (Working Paper Aug. 2005), available at http://ssrn.com/abstract=743144).
} 


\section{Size of Markets (Including Submarkets)}

If one set of products and locations constitute a relevant antitrust market, it is likely that one or more larger sets of products and locations that encompass the initial market would also be an antitrust market. After all, if a hypothetical monopolist of cola-flavored soft drinks, for example, can profitably raise price, it is likely that a hypothetical monopolist of all soft drinks can also do so. ${ }^{67}$ Moreover, markets can overlap. If a hypothetical monopolist of cola-flavored soft drinks can profitably raise price, making cola soft drinks a product market, that does not exclude the possibility that a hypothetical monopolist of Coca-Cola's cola soft drink and Dr Pepper (a non-cola soft drink flavor), but not including Pepsi's cola soft drink, could profitably raise price. ${ }^{68}$

Recognizing the possibility of multiple markets in which the competitive effects of firm conduct could be evaluated allows for more accurate targeting of the competitive effects analysis in each case ${ }^{69}$ It is appropriate to analyze firm conduct in any or all relevant markets in which harm to competition may be found.$^{70}$ To do otherwise, and adopt the contrary view that the smallest possible market satisfying the hypothetical monopolist test conditional on a given starting point be delineated (as suggested in the Horizontal Merger Guidelines), tends to give concentration statistics more prominence than they deserve and to lead competitive effects analysis to turn more on market definition than is necessary or appropriate. ${ }^{71}$ If there are clear breaks in the chain of substitutes-for

\footnotetext{
${ }^{67}$ This example presumes that the smaller market is expanded through the addition of demand substitutes. At a minimum, the hypothetical monopolist of all soft drinks can profitably raise price for the cola-flavored drinks alone.

${ }^{68}$ Moreover, markets could be nested. Suppose product markets must be defined to analyze Coke's acquisition of Pepsi. It is conceivable that starting from Coke, one would define a product market including Coke and Dr Pepper only, while starting with Pepsi, one would need to add first Coke and then Dr Pepper before the market definition algorithm generates a product market. Under such circumstances, competitive effects should be analyzed in both a Coke/Dr Pepper product market and a Pepsi/Coke/Dr Pepper product market. Similarly, to provide another example, in analyzing an allegation of exclusionary conduct involving computer monitors, it is possible that competitive effects should be analyzed in both a monitors market and a broader market for personal computers.

${ }^{69}$ Cf. Pitofsky, supra note 1, at 1812-13 ("The tendency to see relevant market definition as an all-or-nothing proposition rather than as an array of estimates with no market description being exactly right has led to the most serious errors in antitrust enforcement.").

${ }^{70}$ Cf. Katz \& Shelanski, supra note 65 , at 35 (recommending that plaintiffs "not be held to a standard of establishing a unique, bright-line boundary with a high degree of certainty").

${ }^{71}$ This problem is only imperfectly addressed by the discretion the Merger Guidelines provide to vary the SSNIP. Cf. Guidelines Commentary, supra note 29, at 8 ("At times, the Agencies may act conservatively and focus on a market definition that might not be the
} 
example, the distinction between soft drinks and other beverages was once clearer than it appears today-that break may provide a reasonable basis for specifying a candidate market (which must then be analyzed to determine whether demand substitution would likely make a price increase unprofitable for a hypothetical monopolist). But the existence of a market defined by such a clear break does not preclude the possibility of smaller markets delineated by boundaries that seem more arbitrary and difficult to draw. ${ }^{72}$ Those smaller markets would be defined as markets using the same demand-side criteria as apply to the larger market within which they may be nested. In practice, the federal enforcement agencies "frequently conclude that a relatively narrow range of products or geographic space within a larger group describes the competitive arena within which significant anticompetitive effects are possible." 73

The term "submarkets" must be used with care to avoid suggesting that there are circumstances under which the usual demand-side criteria for market definition may be discarded. In the 1962 Brown Shoe opinion, the Supreme Court indicated that "submarkets" could be defined within a broad market, and listed seven "practical indicia" which could be used to do so. ${ }^{74}$ Although many of the Brown Shoe indicia are related to the identification of buyer and seller substitution patterns, some are not. In the past, the practical indicia sometimes have been applied blindly, without reference to the goals of identifying demand or supply substitutability. This has lead to confusion and error: courts have sometimes defined improperly narrow submarkets and, consequently, likely identified market power in settings in which firms were competing vigorously. ${ }^{75}$

\footnotetext{
smallest possible relevant market. ... If the answer for [a] broader market is likely to be the same as for any plausible smaller relevant market, there is no need to pinpoint the smallest market as the precise line drawn does not affect the determination of whether a merger is anticompetitive."). For further discussion of the shortcomings of the "smallest market principle" and related issues, see Jonathan B. Baker \& Steven C. Salop, Should Concentration Be Dropped from the Merger Guidelines?, in ABA Section of Antitrust Law Task Force, Perspectives on Fundamental Antitrust Theory 339 (2001).

${ }^{72}$ For a similar reason, it is often reasonable in practice to expand a candidate market to include a good substitute, regardless of whether the substitute is literally the "nextbest" substitute, the criterion suggested by the Horizontal Merger Guidelines. Merger Guidelines, supra note 5, §1.11.

${ }^{73}$ Guidelines Commentary, supra note 29, at 6-7 (citing as examples markets defined as "superpremium ice cream," paper labelstock used for "variable information printing," paper labelstock used for "prime" labels, and services provided by full-service hospitals in Slidell, La.).

${ }^{74}$ Brown Shoe Co. v. United States, 370 U.S. 294, 325 (1962).

${ }^{75}$ See generally Jonathan B. Baker, Stepping Out in an Old Brown Shoe: In Qualified Praise of Submarkets, 68 Antitrust L.J. 203, 206 (2000); Pitofsky, supra note 1, at 1817 (decrying the "free and easy tendency in the cases to carve out scores and even hundreds of submarkets" during the 1960s and early 1970s).
} 
For this reason, modern courts and commentators are often hostile to the concept of submarkets. ${ }^{76}$ Notwithstanding this caution, submarkets do play a useful role under some circumstances by providing a doctrinal basis for recognizing price discrimination markets ${ }^{77}$ and for addressing the unilateral competitive effects of mergers among sellers of differentiated products. ${ }^{78}$ Otherwise, the submarket terminology is more confusing than helpful and should be avoided.

The scope of the product and geographic markets that would be defined to analyze any particular alleged antitrust violation could differ over time as industry conditions change. For example, a particular merger proposed during one year might be analyzed within local or regional geographic markets. But if the same merger were proposed a few years later, after transportation costs had declined, buyer substitution in response to a small price increase might routinely extend to sellers producing in a larger region, thus calling for a broader geographic market, perhaps national or global. Geographic markets defined in brewing industry merger cases have expanded since the 1960s, for example, perhaps for this reason. ${ }^{79}$

A related issue may arise in high-technology markets when later generation products are introduced (as with computer applications software or video games). Whether earlier as well as later generations should

\footnotetext{
${ }^{76}$ Narrow markets that cannot be described absent multiple adjectives are often ridiculed as gerrymandered-carefully crafted in order to make concentration appear high, rather than defined on a principled basis. See, e.g., United States v. Grinnell Corp., 384 U.S. 563, 591 (1966) (Fortas, J. dissenting) (highlighting "unreality" of the "central station protective services which are "accredited' by insurance companies" market found the by majority by calling it a "strange red-haired, bearded, one-eyed man-with-a-limp classification"). But the number of adjectives is beside the point: the issue is whether the market definition is consistent with the evidence as to demand substitution.

77 See infra Part III.D.

${ }^{78}$ The economic force of buyer substitution underlies the analysis of unilateral competitive effects among mergers among sellers of differentiated products, much as it underlies the analysis of market definition. The advantages and disadvantages of using submarkets to evaluate unilateral effects are explored in Baker, supra note 75, at 209-17.

${ }^{79}$ Compare United States v. Pabst Brewing Co., 384 U.S. 546, 552 (1966) (three-state market including Wisconsin, Illinois, and Michigan), with Christian Schmidt Brewing Co. v. G. Heileman Brewing Co., 753 F. 2d 1354, 1358 (6th Cir. 1985) (12-state upper Midwest market not clearly erroneous; defense would be entitled to prove a broader national market in a later trial on the merits). Moreover, the scope of a market may change over time as buyer demand alters. Suppose, for example, that widgets were originally sold primarily to hobbyists, whose purchases are largely insensitive to price. Widgets would then likely constitute an antitrust product market for analyzing a merger between widget producers. Over time, assume that widget sellers improve the product and lower its cost and price, attracting a large group of new buyers away from some other product, gadgets. If most of the new buyers would substitute back to gadgets in response to a small widget price increase, the product market for analyzing a similar merger may now expand beyond widgets also to include gadgets.
} 
be included in the antitrust product market depends on whether a hypothetical increase in the price of later generation products would be made unprofitable as a result of buyer substitution to earlier generation products (or buyers declining to upgrade). This issue is similar to the question of whether a market for new cars should be expanded to include used cars, or a market for new aluminum should be expanded to include recycled products. There is no general answer: whether to include earlier product generations could differ from one industry to the next, depending on the facts as to demand substitution. ${ }^{80}$

\section{Price Discrimination Markets}

Many firms engage in economic price discrimination-charging different price-cost margins to different buyers of the same product. The Merger Guidelines recognize this possibility by applying the term "price discrimination market" when a hypothetical monopolist of a group of products and locations would raise price profitably to a class of targeted buyers, without raising price to all buyers (or without raising price-cost margins to all buyers to the same degree) ${ }^{81}$ A price discrimination market is defined not just by its products and locations; the definition also must identify the targeted buyers.

Successful price discrimination requires that sellers be able to identify (target) a group of largely captive or loyal buyers, to which price could be raised without inducing substantial demand substitution. ${ }^{82}$ In addition, the discriminating firms must also be able to prevent price discrimination from being undermined through resale. ${ }^{83}$

${ }^{80}$ In United States v. Aluminum Co. of America, 148 F.2d 416 (2d Cir. 1945), a famous monopolization case, Judge Learned Hand defined a primary aluminum product market, excluding secondary (recycled) aluminum. Hand's analysis spawned an economics literature pointing out that a substantial market in used products could, in principle, constrain the price of a new durable good but that a new-product monopolist could offset this competitive force to a significant degree by reducing new production in order to limit the future supply of the used product. See generally GAVIL ET AL., supra note 37, at 578-79 (reviewing economic literature). Whether or not this supply-side force is important (and later empirical economic research concluded that it was not in the Alcoa case because secondary aluminum was only an imperfect substitute to buyers of virgin aluminum), this dynamic is more appropriately evaluated in competitive effects analysis than in market definition, which focuses on buyer substitution not seller behavior.

${ }^{81}$ Merger Guidelines, supra note $5, \S 1.12$. The Merger Guidelines also recognize this possibility when they indicate that the hypothetical monopolist may maximize profits by raising price non-uniformly throughout the candidate market. $I d . \$ 1.12$.

${ }^{82}$ If sellers cannot reliably separate out a group of relatively loyal customers, the profitability of a price increase would depend on the relative number of loyal customers and switchers in the customer pool as a whole.

${ }^{83}$ Accordingly, when defining price discrimination markets, the federal enforcement agencies inquire as to the ability to prevent arbitrage as part of the process of market definition. Guidelines Commentary, supra note 29, at 7. 
The identification of a price discrimination market facilitates the evaluation of the competitive effects of firm conduct by focusing attention on the possibility that sellers could exercise market power with respect to some but not all of their customers. ${ }^{84}$ Courts have employed submarkets to the same effect. ${ }^{85}$

\section{PROBLEMATIC MARKET DEFINITION APPROACHES}

Some approaches to market definition that are sometimes employed perform poorly as methods of identifying buyer substitution and should be avoided. Four problematic approaches are criticized below.

\section{A. Price Comparisons, Including Price Correlations}

Price comparisons are generally not useful as an approach to market definition, whether they involve similarities in price levels, common movements in price over time (price correlations) or stationarity of relative prices (loosely, that the typical relationship between prices, including mean and variance of their difference, does not change over time) ${ }^{86}$ Price comparison methods are commonly defended as testing for arbitrage, ${ }^{87}$ but this economic activity may or may not be related to buyer substitution. Moreover, as a guide to identifying the products or locations that are close substitutes to buyers, the goal of antitrust market definition, price comparison methods can perform poorly.

Price level comparisons mislead as to the bounds of antitrust markets because they ignore the possibility of buyer substitution between highprice/high-quality goods and low-price/low-quality alternatives. ${ }^{88}$ The

\footnotetext{
${ }^{84}$ In one case, involving customized products sold through bidding mechanisms, the Justice Department viewed each individual procurement as a separate price discrimination market. Id. at 8 .

${ }^{85}$ See generally Baker, supra note 75 , at 207-09.

${ }^{86}$ For a recent defense of these methods, see Mario Forni, Using Stationarity Tests in Antitrust Market Definition, 6 Am. L. \& Econ. Rev. 441 (2004). See also George J. Stigler \& Robert A. Sherwin, The Extent of the Market, 28 J.L. \& Econ. 555 (1985). The use of price comparisons to define markets appears to have greater acceptance in European competition practice than in the United States.

${ }^{87}$ These methods are not derived from an arbitrage model, however. Instead, they test for pricing similarities, which might result from arbitrage. For an example of a study that exploits a model of arbitrage to estimate the transactions costs to arbitrage among a set of homogeneous products at different locations, as well as the frequency that arbitrage conditions bind, see Pablo T. Spiller \& Cliff J. Huang, On the Extent of the Market: Wholesale Gasoline in the Northeastern United States, 35 J. Indus. Econ. 131 (1986). Spiller and Huang conclude that the "economic markets" they identify based on arbitrage did not track the markets that would be defined for antitrust analysis.

${ }^{88}$ However, if evidence not involving product price points demonstrates that buyers of some particular high-price/high-quality good would not switch to a low-price/low-quality alternative were the high-quality product to increase in price, the high-quality product
} 
more common approach, relying on price correlations or stationarity tests, also misleads. ${ }^{89}$ One problem is that prices can be correlated because of common shifts in demand, regardless of the extent of buyer substitution. Another is the inherent symmetry of price correlations, which makes it impossible for them to account for the common possibility that sellers of product A constrain the exercise of market power among sellers of product $B$, but not vice versa. For these and other reasons, price correlations can be small when products are close demand substitutes and large when they are not-the reverse of what advocates of this approach to market definition claim to expect. Accordingly, the results of price correlation or stationarity analyses only bear on market definition if sufficient outside information is incorporated to make the empirical exercise something else entirely: tantamount to estimating elasticities of demand..$^{90}$

\section{B. Shipment Flows (Elzinga-Hogarty)}

Geographic markets are occasionally defined based on shipment flows. Under this method, commonly termed the Elzinga-Hogarty approach after the economists who proposed it, ${ }^{91}$ a geographic market is defined as the smallest insular region-the smallest region for which few shipments of the relevant product come from outside ("Little in from Outside") and few shipments go outside ("Little out from Inside") ${ }^{92}$ But shipment patterns at current prices may provide little information about

might constitute a product market, and the bounds of that market might conveniently be described in terms of goods priced above a certain level. See United States v. Gillette Co., 828 F. Supp. 78, 81-83 (D.D.C. 1993) (defining market for premium writing instruments priced between $\$ 50$ and $\$ 400$ ).

${ }^{89}$ See generally Daniel Hosken \& Christopher T. Taylor, Discussion of "Using Stationarity Tests in Antitrust Market Definition,” 6 Am. L. \& Econ. Rev. 465 (2004); Gregory J. Werden \& Luke M. Froeb, Correlation, Causality, and All that Jazz: The Inherent Shortcomings of Price Tests for Antitrust Market Delineation, 8 Rev. Indus. Org. 329 (1993); Jonathan B. Baker, Why Price Correlations Do Not Define Antitrust Markets: On Econometric Algorithms for Market Definition (Federal Trade Comm'n Bureau of Econ. Working Paper No. 149, 1987).

${ }^{90}$ When demand elasticities are estimated using time series data, it may be necessary to test for stationarity in order to properly specify and estimate the demand model, however. For a recent example, see John Hayes, Carl Shapiro \& Robert Town, Market Definition in Crude Oil: Estimating the Effects of the BP/ARCO Merger (Working Paper Aug. 2001), available at http://www.ftc.gov/bc/gasconf/comments2/oilpaperjohnhayesetal.pdf.

${ }^{91}$ Kenneth G. Elzinga \& Thomas F. Hogarty, The Problem of Geographic Market Definition in Antitmerger Suits, 18 Antitrust Bull. 45 (1973); Kenneth G. Elzinga \& Thomas F. Hogarty, The Problem of Geographic Market Definition Revisited: The Case of Coal, 23 AnTITrust BuLL. 1 (1978).

${ }^{92}$ Elzinga and Hogarty variously proposed that $75 \%$ and $90 \%$ of shipments satisfy these tests in order to define a geographic market. In principle, an analogous approach could be employed to define product markets-as a group of products for which buyers purchasing in the product category rarely go outside the set-but in application the approach has been limited to geographic market definition. 
whether buyer substitution would prevent the firms within the region from exercising market power were they to act collectively as though they were a single firm..$^{93}$

In practice, geographic markets defined based on the Elzinga-Hogarty approach can either understate or overstate the regions that would be defined based on the buyer substitution approach of the Horizontal Merger Guidelines. For example, Elzinga-Hogarty markets may understate the geographic market because the locations that buyers patronize at current prices-on which the Elzinga-Hogarty test is based-do not account for the possibility that buyers would substitute more distant locations in the event of a price rise. If sellers at distant locations would ship more into the region in the event prices were to rise, and consequently would constrain the exercise of market power within the region, their distant locations should be included in the geographic market. Moreover, Elzinga-Hogarty markets can overstate the geographic market when the product market includes goods that are not perfect substitutes. Shipments of some goods from outside the candidate region may then incorrectly be taken to suggest that all products in the market could profitably be shipped from outside. In theory, additional information about the way shipment flows would change in response to variation in prices and about product differentiation could be incorporated into the shipments analysis to avoid these problems. But if this adjustment is made properly, the resulting geographic market would be defined based upon buyer substitution and should no longer be described as based upon the Elzinga-Hogarty approach. ${ }^{94}$

\section{Critical Loss Analysis}

Critical loss analysis is a simple form of simulation modeling based on a calibrated relationship between estimates of demand elasticities and price-cost margins. ${ }^{95}$ This approach seeks to determine whether the lost sales from a small price rise instituted by a hypothetical monopolist

\footnotetext{
${ }^{93}$ For criticisms, see, e.g., Gregory J. Werden, The Use and Misuse of Shipments Data in Defining Geographic Markets, 26 AntiTrust Bull. 719 (1981); Janusz A. Ordover \& Robert D. Willig, The 1982 Department of Justice Merger Guidelines: An Economic Assessment, 71 CAL. L. REv. 535, 551-52 (1983); Baker, supra note 27, at 143-48.

${ }^{94}$ In terms of the classification scheme for types of evidence set forth in Part III.A, this adjustments can be understood as using information about the characteristics of products and locations known to matter to buyers in order to assess likely buyer substitution in response to an increase in price.

${ }^{95}$ See generally Barry C. Harris \& Joseph J. Simons, Focusing Market Definition: How Much Substitution Is Enough, 12 Res. IN L. \& Econ. 207 (Richard O. Zerbe, Jr. ed., 1989); Frederick I. Johnson, Market Definition Under the Merger Guidelines: Critical Demand Elasticities, 12 REs. IN L. \& Econ. 235 (Richard O. Zerbe, Jr. ed., 1989).
} 
would exceed a specified fraction of the market, the benchmark "critical loss" beyond which the price increase would not be profitable. ${ }^{96}$

Critical loss analysis is sometimes used as a basis for broadening markets when markups are high. The inference of broad markets from high margins is most commonly based on the following intuition: if the accounting price-cost margin is high, it does not take many lost sales to make a price increase unprofitable, as each lost sale is very costly. Demand would have to be relatively less elastic (relatively unresponsive to price) for that to occur, but that is implausible in a narrow market, so the market is likely broad. As recent economic commentators on the subject of critical loss analysis have emphasized, however, this logic is at odds with a competing intuition: if the accounting price-cost margin is high, the reason may well be that firms have learned that buyers do not readily substitute in response to price increases (demand is relatively inelastic), so the properly defined market is likely to be narrow. ${ }^{97}$

To clarify the issue, suppose that two firms, A and B, are the only producers of prescription sleeping pills. They each charge $\$ 1$ per pill and each has a marginal cost of production and distribution estimated at 25 cents, so the accounting price-cost margin is high..$^{98}$ The industry receives antitrust scrutiny because $\mathrm{A}$ and $\mathrm{B}$ propose to merge. The antitrust decision maker seeks to determine whether prescription sleeping pills are an antitrust product market, as a step in evaluating the likely competitive effects of the transaction.

Assume that there are two possibilities for how the market works, and that in this case, the success of antitrust rules and institutions depends on distinguishing between the two. The first is that competition between $\mathrm{A}$ and $\mathrm{B}$ (perhaps imperfect competition, in the sense of oligopoly conduct) keeps price below the monopoly level of $\$ 1.50$. If so, the merger would permit price to rise to $\$ 1.50$, and would harm competition. The second is that $\mathrm{A}$ and $\mathrm{B}$ are already able to price as though they were a sleeping pill monopolist. They are nevertheless constrained from

\footnotetext{
${ }^{96}$ Alternatively, using the same information in a different way, one might ask whether the demand facing a hypothetical monopolist was so responsive to price-whether the demand elasticity exceeds a benchmark "critical elasticity" level—as to make a price increase unprofitable given accounting price-cost margins.

${ }^{97}$ Daniel P. O’Brien \& Abraham L. Wickelgren, A Critical Analysis of Critical Loss Analysis, 71 Antitrust L.J. 161 (2003); Michael L. Katz \& Carl Shapiro, Critical Loss: Let's Tell the Whole Story, Antitrust, Spring 2003, at 49; James Langenfeld \& Wenqing Li, Critical Loss Analysis in Evaluating Mergers, 46 Antitrust Bull. 299 (2001); Dennis W. Carlton, Using Economics to Improve Antitrust Policy, 2004 Colum. Bus. L. Rev. 283 (2004).

98 The Lerner Index equals 3/4. Under the assumptions that these are single-product producers and that prices today do not affect demand tomorrow, each firm acts as though its elasticity of current period residual demand is $4 / 3$.
} 
charging more than $\$ 1$ by competition from non-prescription sleeping pills, prescription muscle relaxants, allergy medicine, and other alternatives. Under such circumstances, a merger between A and B would not make any difference to the price of prescription sleeping pills.

The central economic issue in this example, on which the antitrust analysis turns, is the magnitude of buyer substitution as the price of prescription drugs rises above its premerger price. The high price-cost margin implies that there was little buyer substitution away from sleeping pills as the price of that product rose to $\$ 1$. If buyer substitution would continue to be limited in the event the price of prescription sleeping pills rose further by a small but significant amount, then prescription sleeping pills should be considered an antitrust product market and the merger found to harm competition. But if there would be substantial buyer substitution to various alternatives in the event price rose further, then the market should be broadened to include those alternatives and the merger found not to harm competition.

The argument about the use of the critical loss approach to market definition revolves around what can be inferred from a high price-cost margin about the magnitude of buyer substitution in the event price were to rise above its current level. One side of the debate, in effect, emphasizes the possibility that firms have already raised price to the point where demand starts to become more responsive to price ${ }^{99}$ The other side more explicitly emphasizes that it is unusual for buyer behavior (here, responsiveness to price) to change abruptly with respect to a small change in the economic environment (here, a small increase in price), ${ }^{100}$ and concludes that it would be more reasonable to presume that buyer substitution would not make unprofitable a small increase in price.

The conundrum posed by these competing perspectives may often be simply resolved: price-cost margins commonly provide limited information about the magnitude of the likely buyer response to an increase in price. Thus, in the prescription drug example, with information limited to the premerger price-cost margin, it is difficult to discriminate between the alternative views as to the scope of the market. For this reason, critical loss analysis is no substitute for a critical analysis of all the evidence that bears on the likely magnitude of buyer substitution and should be

\footnotetext{
${ }^{99}$ This is the economic point implicit in the claim that when price-cost margins are high, it takes few lost sales to make a price increase unprofitable, so if lost sales exceeded that small critical value, the antitrust market would be broad.

${ }^{100}$ See the discussion of "kinks" in demand (by which quantity is more sensitive to a price increase than a price decrease) in Katz \& Shapiro, supra note 97, at 49, 52, and O'Brien \& Wickelgren, supra note 97, at 178.
} 
avoided. Enforcement agencies and litigants can readily be misled when employing critical loss analysis as a simulation tool for market definition if they rely primarily on price-cost margins to infer the demand elasticity, rather than relying upon the other types of evidence emphasized in Part III.C.1 above.

From the perspective of simulation analyses generally, moreover, the critical loss approach embodies a number of simplifying assumptions that do not invariably hold, and can in consequence lead to misleading results. ${ }^{101}$ In some cases, more reliable simulation analyses could be constructed, but if they are it is likely that they could be used to evaluate competitive effects of firm conduct directly, rendering market definition superfluous.

\section{Cluster Markets}

Another approach to market definition defines a product market as a "cluster of services" insulated from competition as a result of their distinctiveness, cost advantages, and settled consumer preference. This approach was adopted by the Supreme Court in several bank merger decisions during the 1960s and 1970s, beginning with Philadelphia National Bank. ${ }^{102}$ In the bank cases, the court clustered commercial banking activity-including loans and other types of credit, deposit accounts, checking services, and trust administration. This cluster of products and services was viewed as distinct from the services offered by savings and loans, finance companies, credit unions, and other financial institutions. Lower courts have extended the cluster concept to a small number of other industry settings, to define markets that include traditional grocery supermarkets, department stores, and acute inpatient care hospital services. ${ }^{103}$

The cluster market approach is inappropriate for market definition because clusters include products and services that are not demand

${ }^{101}$ See generally Gregory J. Werden, Beyond Critical Loss: Tailoring Applications of the Hypothetical Monopolist Paradigm, 4 Competition L.J. 69 (2005); Kenneth L. Danger \& H.E. Frech III, Critical Thinking About "Critical Loss" in Antitrust, 46 ANTitrust Bull. 339 (2001); James Langenfeld \& Wenqing Li, Critical Loss Analysis in Evaluating Mergers, 46 ANTITRust Bull. 299 (2001).

${ }^{102}$ United States v. Philadelphia Nat'l Bank, 374 U.S. 321 (1963).

103 See generally ABA Section of Antitrust Law, Mergers and Acquisitions: UnderSTANDing THE ANTITRUst Issues 60-63 (2d ed. 2004) (surveying cases in which cluster markets have been defined and noting cases where courts have declined to do so). Courts have defined cluster markets to analyze hospital mergers even though the individual services that comprise the cluster are commonly recognized as relevant product markets in nonmerger antitrust cases involving medical services provided by hospitals. See Baker, supra note 27, at $124 \mathrm{n} .161$ (collecting nonmerger hospital services cases in which cluster markets were not defined). 
substitutes (or supply substitutes). It can be defended as a matter of analytical convenience: there is no need to define separate markets for a large number of individual hospital services, for example, when market shares and entry conditions are similar for each, or when data limitations will effectively require that the same proxy (such as the number of hospital beds) be employed to estimate the market share for each individual service. ${ }^{104}$ Or it could be understood as a way of looking to what the allegedly harmed buyers purchase as a basis for specifying the products and locations in the narrowly defined candidate market with which the market definition algorithm begins. ${ }^{105}$ But cluster markets may mislead as to competitive effects when competition from sellers of a partial line of products or services constrains the pricing of the full-line sellers offering the cluster.

A similar type of market definition problem could arise when sellers produce both bundled and unbundled products, for example, if software firms sell suites of products (such as an office productivity suite that includes a word processor, spreadsheet, and presentation program) and also sell the individual component programs on a standalone basis. Suppose suites sell for less than the sum of the prices of the components. If two suite suppliers merge, should the product market for analyzing it be limited to suites?

The answer to this question, as always with market definition issues, turns on the economic force of buyer substitution. If at current prices, one group of buyers (e.g., corporate) purchases office software only as a bundle, and would not consider components, while other buyers (mass market) seek selected software products, the merger might reasonably be analyzed in both a suite market and in markets for the individual components. ${ }^{106}$ But if enough suite buyers would respond to a higher suite price by purchasing instead some components individually, thereby making it unprofitable for a hypothetical suite monopolist to raise price, then the competitive effect of the merger would not be captured by defining a suite market and the transaction should be analyzed in individ-

\footnotetext{
${ }^{104}$ Guidelines Commentary, supra note 29, at 9; Baker, supra note 27 at 123-40.

105 See supra Part III.C.1. Consistent with this perspective, a cluster market may be consistent with a focus on demand substitution when sellers offer buvers substantial transactions cost savings from one-stop shopping. See Ian Ayres, Rationalizing Antitrust Cluster Markets, 95 Yale L.J. 109 (1985).

${ }^{106}$ Market definition would begin with the products each group of buyers, corporate and mass market, purchases (suites for one group, components for the other) and would expand each of those multiple candidate product markets only if a higher price would lead to substantial buyer substitution.
} 
ual component markets only. ${ }^{107}$ Here a competitive effects analysis limited to a suites market could mislead by ignoring the competitive constraint imposed by sellers of individual components, particularly if some sellers offer only some components and not suites.

\section{RETROSPECTIVE HARM CASES}

In some antitrust cases, including most merger reviews as well as agreements or exclusionary conduct evaluated before the conduct has been implemented for long, the alleged harm to competition is prospective. The problem for the enforcement agency or court is to evaluate likely competitive effects in the future, after the conduct under review has taken place. But in other cases, including many monopolization and agreeement matters, the alleged harm has already occurred, so the review is retrospective. This section addresses special issues that arise in market definition in retrospective harm cases, with particular attention to the Cellophane fallacy.

Retrospective harm cases highlight the importance for market definition of identifying the but-for price; that is, the 5 percent or 10 percent price increase in the conceptual experiment for market definition must be measured relative to the price that would have prevailed but-for that conduct. Making this comparison requires careful attention to the allegations in the antitrust case in which market definition is performed. ${ }^{108}$

When the alleged harm is prospective, the price in the but-for world often is taken to equal the currently prevailing price (which, because harm is prospective, is also the price that prevailed before the conduct under review took place). ${ }^{109}$ But if there is reason to believe that the price would decline absent the conduct under review (for example, if production costs are falling rapidly or if entry would have likely occurred

\footnotetext{
${ }^{107}$ The fact that some multi-product sellers produce demand complements (the other programs in the suite) would then be taken into account in the analysis of competitive effects within the individual component markets.

${ }_{108}$ See generally Steven C. Salop, The First Principles Approach to Antitrust, Kodak, and Antitrust at the Millennium, 68 Antitrust L.J. 187 (2000). Cf. Guidelines Commentary, supra note 29, at 5 (the market definition process "is not isolated from the other analytic components in the Guidelines").

${ }^{109}$ Merger analysis at the enforcement agencies, thus, generally grandfathers-in any prior exercise of market power. However, the Merger Guidelines allow the premerger price to reflect the competitive price if there is evidence of coordination premerger. Merger Guidelines, supra note $5, \S 1.11$. This provision can be understood as adopting an implicit presumption that the premerger coordination would break down soon, at least with probability, so that the appropriate but-for price is less than the premerger price.
} 
absent the exclusionary conduct under challenge), then the price in the but-for world would be lower than the currently prevailing price. ${ }^{110}$

The need to define markets with reference to the but-for price can create difficulties for market definition in retrospective cases, where the but-for price is typically disputed. For example, the plaintiff may claim that absent the alleged anticompetitive conduct, the price would be below the level currently prevailing, while the defendant may argue that the conduct under review made no difference to prices so the but-for price is identical to the current price. To isolate the significance of retrospective review for market definition and distinguish it from the separate market definition problems raised by exclusion allegations, this section is concerned solely with market definition when retrospective collusion is alleged. Market definition when retrospective exclusion is alleged (as with many monopolization cases) is discussed in Part VI.

\section{A. Prospective Collusion vs. Retrospective Collusion}

To begin, consider a case in which the alleged harm to competition is prospective. Suppose plaintiff buyers allege that firms A and B have just reached an agreement on a practice that facilitates collusion, and further allege that the conduct will lead to higher prices in the future. ${ }^{111}$ Each firm is assumed to sell a single product, which may be differentiated, and not to discriminate in price. Firms A and B defend by claiming that they could not successfully coordinate pricing because of competition from firm $\mathrm{C}$. The market definition issue in this hypothetical case is whether products A and B (produced by firms A and B, respectively) are collectively an antitrust product market, as plaintiffs contend, or whether that candidate product market must be expanded to include product C (produced by firm C), as defendants argue. This is a familiar market definition question. It can be addressed, in principle, using the hypothetical monopolist approach of the Horizontal Merger Guidelines, based on an assessment of the profitability of a small price increase

\footnotetext{
${ }^{110}$ Under such circumstances, a mere continuation of the prevailing price by a hypothetical monopolist would reflect the exercise of market power, and a candidate market should not be expanded even if prices would likely not rise further. Salop, supra note 108, at 197 (terming the failure to recognize this situation the "Price-Up Trap"). Market definition in exclusion cases is discussed in Part VI. Market definition in rapidly innovating industries is discussed in Katz \& Shelanski, supra note 65, at 36-37 (recommending use of forwardlooking quality-adjusted prices for market definition).

111 The agreement might involve standardizing product definitions or posting prices, for example. This example is framed as an agreement on a facilitating practice rather than as an agreement concerning price in order to make it plausible that a court would analyze the conduct under the rule of reason (rather than a per se rule) and, thus, that the court would define a market as part of its analysis.
} 
among the sellers of products A and B relative to the current price, which plaintiff claims would have prevailed absent the alleged conspiracy.

Now consider the corresponding retrospective case. The prices that firms A and B charge for their products have increased. Plaintiff buyers allege that collusion between the two is the cause, and that price would be lower but-for the alleged agreement. The defendants, firms A and B, explain the price increase as benign, not reflecting an unlawful collusive agreement.

Firms A and B could offer a variety of more specific explanations for the price rise, some of which would implicitly accept the same product market alleged by plaintiffs, limited to products A and B. Explanations that do not contest the product market might include: marginal costs increased for firms $\mathrm{A}$ and $\mathrm{B}$, leading both to raise price; ${ }^{112}$ firm A's marginal costs increased, leading it to raise price, and firm B followed, not competing that price increase away, either because it lacked the ability to expand output inexpensively (e.g., because of capacity constraints) or because it lacked the incentive to do so; or firms A and B raised price through a leader-follower interaction that did not constitute an unlawful agreement, notwithstanding that they may have exercised market power collectively by doing so. None of these "defenses" turn on the economic force at issue in market definition, buyer substitution, so none requires detailed analysis here. ${ }^{113}$

Market definition is a central issue if firms A and B instead argue in their defense that competition from firm $\mathrm{C}$ would have kept prices from rising, had firm C's marginal costs not increased. ${ }^{114}$ Once the constraint from firm $\mathrm{C}$ was removed, firms $\mathrm{A}$ and $\mathrm{B}$ say, they were able to raise price-not through an agreement, but either of necessity because their costs increased too, or as a result of an oligopoly interaction like leaderfollower conduct that did not constitute an unlawful agreement. The market definition argument here is whether to limit the market to products $\mathrm{A}$ and $\mathrm{B}$, as the plaintiffs allege, or to expand that candidate market as proposed by the defense, to include product C. To evaluate this

\footnotetext{
112 The firms may have experienced increased input prices, or higher costs of operating at the greater scale that was required to meet an increase in industry demand, for example.

113 These are "defenses" in the casual sense of explanations, not in a technical legal sense of justifications for what would otherwise constitute a violation.

${ }^{114}$ It is useful to separate out these defenses, although they are not mutually exclusive. There is no reason, moreover, that a court must analyze all claims and defenses raised in a case in the same market, as discussed supra in Part III.C.3. Accordingly, if a broader market is adopted for the purpose of analyzing some issues, that does not preclude the possibility that a more narrow market would be appropriate for analyzing other questions, and vice versa.
} 
allegation, a court should, in theory, analyze the economic force of buyer substitution at a price that would have prevailed absent the alleged conspiracy. How to do so is not obvious in a retrospective case, where identifying the but-for price is at the heart of the dispute.

To clarify this market definition difficulty, suppose that the current price for the products sold by firms A and B, one year after the allegedly anticompetitive conduct has occurred, is 10 , and that a year ago, just before that conduct took place, and thus before any possible collusion, the price was 8 . Assume that a court now seeks to define a product market in order to analyze whether buyer substitution would have prevented the exercise of market power by the sellers of products A and B over the past year, were the price throughout that year at a noncollusive level.

To analyze the significance of buyer substitution for the allegations, the court cannot simply evaluate how buyers in fact responded to the increase in price from 8 to 10 because that issue is tied to the ultimate question in dispute, which market definition is intended to help analyze. Plaintiffs may observe that the price increase is consistent with their view that buyers were unable to prevent higher prices by substituting to product $\mathrm{C}$. But the defendants may respond by pointing out that the price increase for products $A$ and $B$ is equally consistent with their view that substitution to product $\mathrm{C}$ would have constrained price to stay at 8 had firm C's costs not increased, and that buyer substitution to product $\mathrm{C}$ continues to constrain the price charged by firms $\mathrm{A}$ and $\mathrm{B}$ not to rise above the now-higher noncollusive price level of 10 . If the court could determine directly whether the current price of 10 is a competitive or a collusive price, given the way costs have changed over the past year, it could resolve the dispute without need for market definition, using direct evidence. But if direct evidence is unavailable or not strongly probative, making market definition necessary or useful, the court will likely need to define the market through undertaking a hypothetical prospective market definition analysis (albeit relying importantly on retrospective evidence).

\section{B. Retrospective Collusion and the Cellophane Fallacy}

In particular, if market definition is nevertheless undertaken in the above example, the court must find some way to obtain information about buyer substitution at the unknown but-for price. One approach would evaluate how buyers would have responded to a hypothetical higher price for products $\mathrm{A}$ and $\mathrm{B}$ one year ago, just before the conduct under review took place, when the price of 8 was known not to be affected by the alleged collusion. After all, the price of 8 one year ago 
is the last noncollusive starting point acknowledged by both parties. Accordingly, the court could conduct a prospective market definition inquiry, looking to what was known about likely buyer behavior at that earlier time. Products A and B would be defined as a market if a hypothetical monopolist of those products then would have found it profitable to raise price above 8 , after accounting for buyer substitution to all sources, including product $\mathrm{C}$. This approach would be appropriate conceptually to the extent it is plausible that buyer substitution patterns at the last price both sides accept as pre-collusive would be similar to buyer substitution patterns at the but-for price today (regardless of whether plaintiff or defendant is correct as to their view of the level of the butfor price relative to the currently prevailing price). ${ }^{115}$ Moreover, this approach may be practical if it is possible to learn about buyer substitution patterns at the pre-collusive time and price. ${ }^{116}$

More commonly, perhaps, courts and enforcers attempt to evaluate how buyers respond to a hypothetical price change for products A and B today, when the price is at the higher level of 10. In order for this approach to make sense when the but-for price is unknown, it can be thought of as an attempt to recreate the previous approach using different information. That is, this approach seeks to determine how buyers would have responded to a hypothetical higher price for products A and $\mathrm{B}$ one year ago, when the price was 8 , by using information about the response of buyers to price changes since that time, notwithstanding that the price has increased and costs or other factors determining price may have changed. Although buyer substitution may be measured at the current price of 10, therefore, doing so may be understood as developing evidence from which the magnitude of buyer substitution at the previous price of 8 could be inferred. Knowledge of the magnitude of buyer substitution at that earlier time and price, it bears repeating, is not relevant to resolving the antitrust dispute today for its own sake but because it is often plausible that the magnitude of buyer substitution at the last acknowledged pre-collusive price is a reasonable guide to buyer

\footnotetext{
${ }^{115}$ This inference would be less plausible to the extent that buyer substitution patterns have changed, for example, because of changes in the available mix of products, changes in buyer income, or changes in buyer tastes. Under such circumstances, what is learned about buyer substitution patterns at the price of 8 one year ago would need to be modified to account for those changes in order to make inferences about buyer substitution patterns at the but-for price today.

${ }^{116}$ Some types of evidence about buyer substitution then may be available for a court to consider now. For example, it may be possible to obtain information about how buyers responded to even earlier price changes, or seller documents from one year ago may be available identifying which rivals they monitored and responded to at that time. But the longer ago the alleged conspiracy began, the more difficulty it may be to obtain such evidence.
} 
substitution now, at the unknown price that would have obtained butfor the alleged anticompetitive practice.

It is necessary to engage in these mental gymnastics rather than taking evidence about buyer substitution at the price of 10 at face value because the plaintiff claims that the current price is not a noncollusive but-for price but instead reflects the operation of the alleged unlawful agreement. If the plaintiff is correct, the analysis of buyer substitution at the price of 10 may mislead as to whether the economic force of demand substitution would have prevented collusive conduct by firms A and B. This possibility is termed the Cellophane fallacy. ${ }^{117}$ The problem arises because firms exercising market power may boost prices to a point at which further price increases are made unprofitable, constrained by the threat of demand substitution. Under such circumstances, an approach to market definition that infers buyer substitution from a small hypothetical price increase over the currently prevailing price-the usual practice in market definition analysis when the alleged harm to competition is prospective-may make buyer substitution appear to be greater than it was when price was at the noncollusive (but-for) price level, under the plaintiff's view that the but-for price was lower.

As previously noted, one would, in principle, like to start the market definition at the lower price that would have obtained today absent any anticompetitive conduct, and ask whether a hypothetical price rise would be profitable. But this idea cannot be implemented directly, as the question of whether price would in fact be lower absent the conduct challenged by the plaintiffs is a central issue in dispute. ${ }^{118}$ Instead, the most practical alternative, as suggested above, may be to use what is known about buyer substitution at the current price to make inferences about the magnitude of likely buyer substitution had a hypothetical monopolist of products A and B raised price a year ago, when the price was at the acknowledged noncollusive level of 8 . One way to learn about buyer substitution when working from today's price, while reducing the potential for a Cellophane fallacy bias, is to ask whether a small price reduction from the prevailing price level would or would not lead buyers to substitute away from outside products and locations to the products and locations in the candidate market in substantial numbers. ${ }^{119}$ But if this

\footnotetext{
117 This well-known difficulty is named for a conceptual error made by the Supreme Court in defining the product market in United States v. E.I. du Pont de Nemours $\mathcal{E}^{\circ}$ Co., 351 U.S. 377 (1956) (Cellophane).

${ }^{118}$ In any case, independent knowledge of the competitive price would likely permit proof or disproof of harm to competition by direct evidence, making market definition unnecessary.

${ }^{119}$ A similar approach is proposed in Philip B. Nelson \& Lawrence J. White, Market Definition and the Identification of Market Power in Monopolization Cases: A Critique and a
} 
analysis suggests substantial buyer substitution, consistent with the defendant's view of the market, it is still open for the plaintiff to argue that buyers would not have been so willing to substitute away from products A and B had the price been lower, as the plaintiff claims would have occurred but-for the alleged conspiracy. ${ }^{120}$

The idea that the magnitude of buyer substitution at the currently prevailing price can be understood as an estimator of the magnitude of buyer substitution that would have occurred in the past at the price observed before the allegedly anticompetitive conduct took place, helps clarify how to calibrate that magnitude-to determine how much buyer substitution is consistent with a market limited to products A and B and how much more would suggest broadening the market to include product $\mathrm{C}$. When buyer substitution is assessed at the currently prevailing price in a retrospective case, it cannot be calibrated with reference to profitability today, for example, by asking whether the hypothesized price reduction would increase current profits. Given that current prices are set by profit-maximizing firms, any price reduction would cause the profit of the firms selling in that market to decrease. But it does make sense to ask whether a hypothetical monopolist of products $\mathrm{A}$ and $\mathrm{B}$, created when all would agree that the price did not reflect the effect of the practices under review (that is, last year, when the price was 8), would have found it profitable to raise price a small amount. Although this question may sound difficult to answer, the task may at times be easy. In some markets, it may be reasonable to conclude simply from observing relatively elastic demand for products $\mathrm{A}$ and $\mathrm{B}$ that the market should be expanded to include the products sold by firm C, and in others it may be reasonable to conclude simply from observing relatively less elastic demand for products A and B that the market should not be expanded this way.

\section{Collusive Conduct Alleged to Prevent Price from Deglining}

In some cases, the alleged collusive conduct is said to have prevented price from declining, rather than to have led to a price increase. To clarify the resulting market definition issue, assume that the currently

Proposal (NYU Center for Law \& Business Working Paper No. CLB-03-022 Nov. 2003), available at http://w4.stern.nyu.edu/emplibrary/03-022.pdf. This approach is equivalent to starting with the current output and asking whether a substantial increase in supply within the candidate market would not or would lead to only a small reduction in price.

${ }^{120}$ That is, it is still open for the plaintiff to argue that demand would have been relatively inelastic at the lower price that allegedly would have obtained absent anticompetitive conduct, making the alleged exercise of market power profitable, notwithstanding that demand is somewhat more elastic at a price near but slightly lower than the current price. 
prevailing price is 10 , as was the price one year ago, when the conduct under review occurred. Plaintiff's argument is that price would have fallen to 8 (for example, to reflect a decrease in marginal costs) but that collusion between firms A and B kept price at 10. Again the price butfor the allegedly anticompetitive conduct is in dispute: the plaintiff says 8 while the defendant says 10 . If the best evidence about the magnitude of buyer substitution in this case involves buyer substitution today at the current price of 10 , that information can be understood as evidence of buyer substitution patterns both at the generally acknowledged preconspiracy price of 10 one year ago and at the unknown potentially lower but-for price today. ${ }^{121}$ An analysis of the profitability of a hypothetical price increase one year ago, given costs then (before costs fell according to plaintiff), could then be used to make an inference about the profitability of a hypothetical price increase from the unknown but-for price today.

The problem of proof for market definition may be more difficult when the claim is that defendant's conduct prevented price from declining. But in concept, following the chain of logic set forth above, market definition should proceed similarly to the approach that would be used when the plaintiff claims that the defendant's conduct led to an anticompetitive price rise.

\section{EXCLUSION, PROSPECTIVE AND RETROSPECTIVE}

Allegations of antitcompetitive exclusion raise special issues for market definition, some of which are particularly difficult when the alleged harm is also retrospective. To think about defining markets in retrospective exclusionary conduct cases, it is again useful to start with the corresponding prospective harm case.

\section{A. Prospective Exclusion}

Consider the following hypothetical example, similar to the collusion example discussed above in Part V. Firm A competes with firm B and, possibly, with firm C. All firms produce single products (product A by firm A, etc.) and do not discriminate in price. Products may be differentiated. Firm A has just engaged in conduct that firm $B$ believes will exclude firm B, by forcing firm B to compete less aggressively (reducing

If so, the price reduction approach may reduce the Cellophane fallacy problem without avoiding it entirely.

${ }^{121}$ Again, buyer substitution today may be measured by assuming a hypothetical price reduction, to reduce the Cellophane fallacy problem. 
output) or even to exit the market entirely. ${ }^{122}$ The case is prospective because the harm to firm B has not yet occurred. To simplify the exposition, the discussion below will presume that exclusion would be complete, not partial, and that firm B would be forced to exit.

Firm B contends that firm A's exclusionary conduct will harm competition by allowing firm A to raise price. ${ }^{123}$ Firm A offers two "defenses" to explain why price increased. ${ }^{124}$ First, firm A claims that the exit of firm B would not lead firm A to raise price because firm B does not significantly constrain firm A's pricing. For example, firm A may argue that firm B is a small, high-cost producer unable to expand output inexpensively, or that most buyers do not view product $\mathrm{B}$ as a close demand substitute for product A. Second, firm A claims that the exit of firm B would not lead to a price increase because firm $\mathrm{C}$ has the ability and incentive to expand output to replace any competition that would be lost. (Firm A also may provide a procompetitive justification for the alleged exclusionary conduct, for example, explaining why its action reduced firm A's costs or increased product quality, but that aspect of the litigation is not explored further here.)

The market definition issue in evaluating this prospective exclusion case depends on the details of the allegations and defenses because those specifics clarify the appropriate but-for world. The dispute implicated by firm A's first defense, concerning the importance of the constraint posted by firm B on firm A's pricing, may raise a buyer substitution issue appropriate for analysis through market definition-if firm A argues more specifically that firm B is unimportant competitively because product $\mathrm{B}$ is not a close demand substitute for product A for most buyers. To evaluate this claim, a court should begin by asking whether product $\mathrm{A}$ constitutes a relevant antitrust market, excluding product $\mathrm{B}$, or whether the candidate market should instead be expanded to include

\footnotetext{
${ }^{122}$ Perhaps firm A's conduct or practices would restrict the ability of firm B to obtain key inputs or obtain access to customers, or they would lead to the destruction of firm B's plant.

${ }^{123}$ Firm B might claim that firm A had harmed competition through monopolization, exclusive dealing, tying, group boycott, or agreement (possibly vertical) or merger, for example; the specific antitrust violation alleged would depend upon whether the necessary legal elements are met. It is assumed that firm B alleges that it was harmed by the conduct that allegedly harmed competition, leading to higher prices, and, thus, that the injury alleged by firm B would count as antitrust injury.

${ }^{124}$ Again, these are "defenses" in the casual sense of explanations, not in a technical legal sense of justifications for what would otherwise constitute a violation. It is useful to separate them, although they are not mutually exclusive. They may also be related, in that the less significant a competitive constraint firm B poses, the easier it may be for firm $\mathrm{C}$ to replace the lost competition. As previously noted, there is no reason that a court must analyze all claims and defenses in the same market.
} 
product B. ${ }^{125}$ This is a familiar question, which a court should address by asking whether a hypothetical monopolist of product A would find it profitable to raise price above the prevailing level. If instead firm A argues that firm B is unimportant competitively because firm B is a small, high-cost producer unable to expand output inexpensively, ${ }^{126}$ firm $\mathrm{A}$ is effectively conceding that product B is in the market, and is raising a supply-side issue that would be analyzed within the market consisting of products A and B. ${ }^{127}$

The market definition issue in the dispute over the ability and incentive of firm $\mathrm{C}$ to replace any lost competition, the question raised by firm A's second defense, turns on what the plaintiff, firm $B$, argues in response. One possibility is that firm B contends that firm $\mathrm{C}$ lacks the ability to constrain firm A's pricing because product $\mathrm{C}$ is not a close enough substitute in demand. This is a market definition issue, which a court should evaluate by asking whether a hypothetical monopolist of products $\mathrm{A}$ and $\mathrm{B}$ would find it profitable to raise price above the prevailing level, or whether instead the market should be expanded to include product C. ${ }^{128}$

Other possible responses by firm B-that firm $\mathrm{C}$ cannot inexpensively expand output, or that firm $\mathrm{C}$ lacks the incentive to constrain firm A's pricing and in the absence of firm $B$, firm $C$ would instead tacitly collude with firm A-are supply-side questions that presume that the antitrust

\footnotetext{
${ }^{125}$ If firm A also points in defense to the ability and incentive of firm $\mathrm{C}$ to replace any competition lost from the exit of firm $\mathrm{B}$, a court may also analyze whether a candidate product market consisting of products $\mathrm{A}$ and $\mathrm{C}$ should be expanded to include product $\mathrm{B}$.

${ }^{126}$ The implication for market definition is similar if firm A argues that firm B had the ability but not the incentive to compete aggressively with it, as the nature of the oligopoly interaction is also a supply-side issue. This claim about firm B's incentive may be an unattractive argument in the context of the hypothetical example, however, as it is tantamount to suggesting that firm A should be allowed to exclude firm B on the ground that the two were already colluding tacitly, so that there would be no loss of competition if firm B were to exit.

${ }^{127}$ This question may also be analyzed within a market consisting of products $\mathrm{A}, \mathrm{B}$, and $\mathrm{C}$, if competition from firm $\mathrm{C}$ represents an important constraint on firm A's pricing.

${ }^{128}$ Similarly, suppose A is a joint venture rather than a single firm, and the plaintiffs are a group of potential members B which claim that the joint venture will harm competition by excluding them. Suppose further that the venture defends by arguing that the alleged exclusionary conduct could not matter because the joint venture was constrained not to raise price by firms selling product $\mathrm{C}$. The market definition question relevant to evaluating the allegation and defense is whether the relevant antitrust market includes the products and locations of both the members of the joint venture and the potential members (to include the products of firms A and B), or whether it must expanded further (also to include the product of firms C). See Dennis W. Carlton \& Steven C. Salop, You Keep on Knocking but You Can't Come in: Evaluating Restrictions on Access to Input Joint Ventures, 9 HaRv. J.L. \& Tech. 319, 346-47 (2006).
} 
market includes products A, B, and C. ${ }^{129}$ With respect to analyzing these "defenses," a court should accept the market assumed by both partiesthere is no dispute as to market definition-and move on to consider the supply-side question on which these defenses turn. ${ }^{130}$

\section{B. Retrospective Exclusion and the Cellophane Fallacy}

Now consider the corresponding retrospective exclusion case. Firm B has exited the market. It alleges that firm A's exclusionary conduct forced it to exit, and that the effect was either to raise price or to prevent a price decline that otherwise would have occurred. Firm A's possible defenses are analogous to those it would have offered were the case prospective: (1) the exit of firm B made no difference to firm A's pricing because firm B did not pose a significant competitive constraint; and (2) any loss of competition from the exit of firm B was replaced by an increase in competition by firm C. Because this is a retrospective case, firm A presumably also argues that if price increased since the time of the challenged conduct, the price rise resulted from a benign cause, most likely an increase in industry marginal cost or an outward shift in demand (if marginal costs are increase as output rises), and was not related to a loss of competition. ${ }^{131}$ (Again, firm A may also provide a procompetitive justification for the alleged exclusionary conduct, but this aspect of the litigation will not be discussed further.)

Market definition again depends on the details of the allegations and defenses the parties make. ${ }^{132}$ The role of market definition in addressing

\footnotetext{
${ }^{129}$ If firm B defends by claiming that firm C would replace any lost competition, the magnitude of buyer substitution from products $A$ and $B$ to product $\mathrm{C}$ is a relevant consideration because it affects the size of the competitive response by firm $\mathrm{C}$ that would be necessary. This buyer substitution issue would be treated as part of the competitive effects analysis, along with the supply-side question of the extent to which firm $\mathrm{C}$ expanded output, in much the way that the buyer substitution issue of unilateral effects of merger among sellers of differentiated products is treated as a competitive effects issue rather than a market definition question.

${ }^{130}$ Again, these defenses are not mutually exclusive, and the fact that a court adopts a market for the purpose of analyzing some issues does not preclude the possibility that a different market, possibly broader or more narrow, would be appropriate for analyzing other questions.

${ }^{131}$ Accordingly, direct evidence on whether price changes are fully explained by shifts in cost and demand, without the need to postulate an increase in market power, could, in principle, discriminate between plaintiff's theory of the case and the defense theory. In an appropriate case, therefore, direct evidence of this nature could resolve the case without need for market definition. The discussion in the text presumes that the available direct evidence is not strongly probative in the case at issue and that it is also worth analyzing the evidence concerning market structure.

${ }^{132}$ As should be evident, a complete economic analysis of the exclusion allegation would not be limited to market definition because market definition and the market shares that result do not necessarily determine fully whether the alleged conduct harms competition.
} 
firm A's first defense depends on why, according to firm A, firm B did not pose a significant competitive constraint.

Suppose first that firm A contends that firm B could not have constrained firm A because few buyers of firm A's product would have responded to a higher price by switching to firm B's products at the time of the exclusionary conduct. This claim raises a market definition problem. Here, firm A is arguing in its defense that product B was not part of the antitrust market at the time of the exclusionary conduct, when price was at the pre-exclusion level. Firm A is claiming either that the market was limited to product $\mathrm{A}$, excluding product $\mathrm{B}$, or that it included products $\mathrm{A}$ and $\mathrm{C}$ but not product $\mathrm{B}$. In principle, therefore, a court should evaluate this allegation by analyzing whether, at the time of the alleged exclusionary conduct, the product market was limited as alleged by firm $\mathrm{A}$ and did not include product $\mathrm{B}$.

The relevant price at which demand substitution is assessed, again in principle, would be the price in the but-for world, which is disputed by the parties. But again it is undisputed that the pre-exclusion price did not reflect the alleged loss of competition. In theory, therefore, a court or enforcer could attempt to gauge the extent of buyer substitution and determine whether the market should be limited to product $\mathrm{A}$ (or products $\mathrm{A}$ and $\mathrm{C}$ ) to the exclusion of product $\mathrm{B}$, at the price prevailing just before the alleged exclusionary conduct occurred and under the other conditions (particularly costs and demand) prevailing at that time. This analysis, again in principle, could identify the extent to which buyer substitution would have prevented a hypothetical monopolist of product A (or products A and C), charging the unknown but-for price after the alleged exclusionary conduct has occurred, from exercising market power.

In practice, a court or enforcer may instead analyze buyer substitution after the exit of firm B and at the currently prevailing (post-exclusion) price. Although this would technically be evidence of demand substitution at the wrong time and wrong price, it may still probative of the magnitude of demand substitution at the right time and price-unless

Regardless of the scope of the market and the market shares of the firms, a range of other economic considerations not involving demand substitution would likely be relevant to identifying the competitive effects of the challenged conduct. These may include whether firm B actually was excluded; whether firm A's conduct was responsible; whether the exclusion of firm $\mathrm{B}$ harmed competition by conferring additional market power on firm A; whether benefits to competition from the exclusionary conduct outweigh the harms; and whether more aggressive competition from firm $\mathrm{C}$ replaced any competition lost from the exclusion of firm A. This essay does not address the legal question of whether truncated doctrinal rules, possibly based on market shares, should or do limit consideration of some or all of these issues in the courts. 
there is reason to think that demand substitution patterns have changed since the pre-exclusion period, or unless there is reason to think that demand substitution patterns at the pre-exclusion price differ from demand substitution patterns at the post-exclusion but-for price.

In particular, the Cellophane fallacy issue can be understood as suggesting the latter possibility: as a claim that demand is more responsive to price at the current price than it would be at the lower but-for price, with which market definition should be concerned. One way to address this problem to some extent, as discussed above in Part V.B, is to analyze how buyers would respond to a price reduction from the currently prevailing price. ${ }^{133}$

As with the retrospective collusion example of Part V, the idea that the magnitude of buyer substitution at the currently prevailing price can be understood as an estimator of the magnitude of buyer substitution that would have occurred in the past, at the price observed before the allegedly anticompetitive conduct took place, helps clarify how to determine how much substitution is enough and how much is too much to maintain a candidate market. In a retrospective harm case, if buyer substitution is assessed in the neighborhood of the prevailing price, its magnitude cannot be calibrated with reference to current profitability. ${ }^{134}$

\footnotetext{
${ }^{133}$ In the exclusion context, this methodology may be more challenging to implement than the corresponding question in a prospective harm case. If firms A and B sell differentiated (rather than homogeneous) products and if firm B has exited, it may be necessary to assess the effects of buyer decision making of two simultaneous hypothetical changes in their economic environment, including one (the exit of firm B) that is not a marginal change, by which both prices and products differ from those presently available. If firm A has changed its product offerings or locations in response to the exit of firm B, it may also be necessary to assess the effects of a third simultaneous hypothetical change in the economic environment.

${ }^{134}$ Given that current prices are set by profit-maximizing firms, any price change would cause the profit of the firms selling in that market to decrease. A technical example will clarify what can be learned in principle from analyzing the magnitude of demand substitution at current prices. Assume that firm A sells a single product and does not discriminate among buyers, firms A and B sell homogeneous products, and firm B has exited the market entirely. Then the first order condition for profit-maximization by firm A can be written: $\mathrm{L}=1 /\left[\varepsilon-\varepsilon_{\mathrm{ac}} \theta_{\mathrm{ca}}\right]$. Here $\varepsilon$ is the own-price elasticity of demand for product $\mathrm{A}, \varepsilon_{\mathrm{ac}}$ is the cross-elasticity of demand for product $\mathrm{A}$ with respect to the price of product $\mathrm{C}$, and $\theta_{\mathrm{ca}}$ is the (perceived) elasticity of the price response of product $\mathrm{C}$ with respect to the price of product $\mathrm{A}$-all measured at the currently prevailing price, which post-dates the exit of firm B. The right-hand expression as a whole represents the inverse of the demand elasticity perceived by firm A. In terms of this framework, firm B alleges that its exclusion caused $\varepsilon$ to fall, leading price (and thus the markup L) to increase. Firm A has a number of possible defenses: denying that the exit of firm $B$ altered $\varepsilon$, arguing that $L$ did not rise as any price increase was explained fully by an increase in marginal cost, or claiming that any reduction in $\varepsilon$ was compensated for by an increase in competition from firm $\mathrm{C}$ (altering $\left.\varepsilon_{\mathrm{ac}} \theta_{\mathrm{ca}}\right)$. Here a comparison of the Lerner Index with the inverse of the perceived demand elasticity proves nothing about market definition, as the two must be equal for a firm
} 
Instead, a court can determine whether product A (or products A and $\mathrm{C}$ collectively) is a market, excluding product $\mathrm{B}$, by asking whether a hypothetical monopolist of the products in the candidate market before the alleged exclusionary conduct took place would have found it profitable to raise price a small amount, considering costs, products and demand as they were then. ${ }^{135}$

Alternatively, firm A may defend by arguing that any loss of competition from the exit of firm B was replaced by an increase in competition by firm C. Now the market definition dispute between the parties is over whether the product market consists solely of products A and B (as the plaintiff presumably claims), or whether it should be expanded to include product $\mathrm{C}$ as well.

The analysis here is similar to that of the previous case. A court would like to measure buyer substitution at the unknown price that would have prevailed but for the alleged exclusionary conduct, and determine whether a hypothetical monopolist of products A and B could profitably raise their price. Because the but-for price is in dispute, the court may instead seek to determine whether a hypothetical monopolist of those products would have found it profitable to raise price in the past, at the time of the exclusionary conduct, given the demand (buyer substitution) and cost conditions prevailing then. This alternative conceptual experiment would reasonably substitute for the appropriate conceptual experiment that is impossible to implement (because the but-for price is unknown), so long as there is no reason to think demand and cost conditions varied between the date of the alleged exclusionary conduct (when price was at the observed past level) and the present time (were

maximizing profits, and a comparison of the Lerner Index with the inverse of the ownprice elasticity $\varepsilon$, with both measured at the currently prevailing price, could at best reveal that firm $C$ imposes virtually no competitive constraint on firm $A$ (because $L \approx 1 / \varepsilon$ if competition from firm $\mathrm{C}$ is unimportant in determining the price set by firm $\mathrm{A}$ ) and, consequently, suggest in that special case that the market should not be expanded beyond products $\mathrm{A}$ and $\mathrm{B}$.

In thinking about the first-order condition $L=1 /\left[\varepsilon-\varepsilon_{a c} \theta_{c a}\right]$, it is useful to note that the own and cross-elasticities of demand may be related. In particular, if product $\mathrm{A}$ competes with products B and C, then $\varepsilon=1+\left(\mathrm{s}_{\mathrm{b}} / \mathrm{s}_{\mathrm{a}}\right) \varepsilon_{\mathrm{ba}}+\left(\mathrm{s}_{\mathrm{c}} / \mathrm{s}_{\mathrm{a}}\right) \varepsilon_{\mathrm{ca}}$, where $\varepsilon$ is the ownprice elasticity of demand for product $\mathrm{A}, \varepsilon_{\mathrm{ba}}$ and $\varepsilon_{\mathrm{ca}}$ are cross-price elasticities, and $\mathrm{s}_{\mathrm{a}}, \mathrm{s}_{\mathrm{b}}$, and $s_{c}$ are the shares of buyer expenditures in the product category (the three products as a group). (This equation is derived by differentiating total expenditures with respect to the price of product A, holding expenditures constant. Expenditure shares are based on price times quantity, not simply quantity.)

${ }^{135}$ Continuing the example of the previous note, if the own-price elasticity $\varepsilon$ measured post-exclusion is used as an estimator of its pre-exclusion value (notwithstanding the Cellophane fallacy problem), then whether product A is defined as a market would turn on a comparison between that elasticity and the Lerner Index measured at the previous (pre-exclusion) price and marginal cost. 
price at the unknown but-for level), or that if conditions varied, those changes can be accounted for. If information about buyer substitution in the past, at the price observed before the alleged exclusionary conduct, is unavailable or not strongly probative, it may be estimated using information about buyer substitution at the currently prevailing price, based on a hypothetical price reduction to reduce the impact of the Cellophane fallacy problem and making any additional adjustments that might be found appropriate.

Careful calibration may not be necessary in practice in defining markets in retrospective exclusion cases. For example, it may be reasonable to conclude simply from observing relatively elastic demand for products $\mathrm{A}$ and $\mathrm{B}$ that the market should be expanded to include the products sold by firm C. In other cases, it may be reasonable to conclude simply from observing relatively less elastic demand for products $\mathrm{A}$ and $\mathrm{B}$ that the market should not be expanded this way. In all cases, retrospective and prospective, collusion and exclusion, the focus of market definition should be on the magnitude of buyer substitution.

\section{CONCLUSION}

Market definition is the primary method by which antitrust analysis accounts for the economic force of demand substitution in evaluating the competitive effects of firm conduct. To avoid confusion and clarify the inquiry, market definition should be limited to the consideration of demand substitution; other economic forces like supply substitution can readily and appropriately be accounted for in other steps of antitrust analysis. Moreover, market definition does not take place in a vacuum: in any particular case, demand substitution must be evaluated with reference to the specific allegations of anticompetitive effect in the matter under review. These principles help identify the types of evidence relevant to defining markets. They also have been used to analyze a number of conceptual and practical issues in market definition, and to explain the difficulty with several problematic approaches to market definition that are sometimes employed. 